\title{
3. Film and the Other Arts
}

\begin{abstract}
In this chapter, I situate Bazin's studies on film and painting within a postwar endeavor to renew artistic forms and to revive their social implication, which crystallizes in an encounter with the French existentialist philosopher Gabriel Marcel (1889-1973) and Swiss biologist Adolphe Portmann (1897-1982). From there on, I pinpoint certain specifically cinematographic aspects, both on film and in painting, to support Bazin's notion of a 'myth of total cinema'.
\end{abstract}

Keywords: film and painting, myth, Vincent van Gogh, Pieter Bruegel

Er ligt een lijk onder het struikgewas. Vier eeuwen na zijn dood zag men het pas, als in Blow Up, maar op z'n Boeren-Breughels

[A corpse lies under the shrubs.

It took four centuries for people to find, as in Blow-Up, but in Peasant Bruegel-style].

Jan Kal, 1974

The first time you stood in front of this painting, your eye was immediately drawn to the ploughman's red shirt. Later on, discovering Icarus on the right, you smiled. Immediately, then, a strange litany started to reverberate in your head. It continued all afternoon: a man works his field; a shepherd looks at the sky; a boat slowly navigates towards a port; the sea is calm; a man is drowning. Claudio Pazienza, 1997

The prominence of painting in Bazin's oeuvre is exemplified by the contextual framework it sketches from the first version of 'The Ontology

Joret, B., Studying Film with André Bazin, Amsterdam: Amsterdam University Press, 2019 DOI: $10.5117 / 97894629895^{28 / \mathrm{CHO}}$ 
of the Photographic Image', published in a collected volume Problems of Painting (1945): in it, painting functions as a counter-reference to cinema. Photography and by extension cinema have changed painting because they freed '[the visual arts] from the obsession of resemblance.' The initial interest in painting thus accompanies Bazin's film criticism from the very beginning and culminates in his later essays, where he further develops this thesis in support of an 'impure cinema' into a series on cinema and painting (1949) and its relation to theater ('Theater and Cinema', 1951) and literature ('For an Impure Cinema', 1952). For Bazin, film defines itself in a constant dialogue with other art forms to address contemporary societal issues, post-war apathy specifically. We know from his correspondence with his close friend Guy Léger in 1940 that Bazin's depression caused by the Nazi invasion of France had everything to do with his 'guilt at being so far from the front, but he realized that his urge toward self-sacrifice was hardly patriotic. It stemmed, he said, from a massive sense of personal worthlessness'. ${ }^{2}$ Later that year, Bazin actively engaged with others in 'sorting out the political, philosophic, and moral disaster that had fallen on their country and was being accepted with disgusting effortlessness'. ${ }^{3}$ Bazin's firm belief in a fundamentally social aesthetic of film can thus be viewed in light of a cultural movement that sought in the arts the moral re-armament against social apathy. From this perspective, his particular concern with cinema and other arts is informed by both his rejection of medium essentialism as well as with his views on cinema's social dimension.

In this chapter, I situate Bazin's studies on film and painting within a postwar endeavour to renew artistic forms and to revive their social implication, which crystallizes in an encounter with the French existentialist philosopher Gabriel Marcel (1889-1973) and Swiss biologist Adolphe Portmann (1897-1982). From there on, I pinpoint certain specifically cinematographic aspects, both on film and in painting, to support Bazin's notion of a 'myth of total cinema' with a specific emphasis on the myth of Icarus in Bazin's oeuvre, in painting as well as in poetry. From Bazin's writings on Vincent van Gogh, as well as those of Antonin Artaud and Georges Bataille, I argue for a particularly realist film language.

1 Bazin, 1945, EC p. 2556; Transl. Barnard, 2009, p. 7; On the role of painting in Bazin's ontology essay, see for example, Joubert-Laurencin, 2014, pp. 63-67.

2 Andrew, 2013, p. 33.

3 Ibid., p. 34 . 


\subsection{Debates on Contemporary Art: Bazin, Marcel and Portmann}

In 'For an Impure Cinema', Bazin firmly embeds his anti-essentialist mind-set in the existentialist lemma, 'existence precedes essence', ${ }^{4}$ a common denominator under which Jean-Paul Sartre places himself alongside Gabriel Marcel, despite the latter's outspoken Christian perspective. ${ }^{5}$ While it is in these Sartrian terms that Bazin's general views on film history can be explained, his association with Marcel, as a literary critic, playwright and a philosopher, remains to this day unconfirmed. As mentioned in the previous chapter, Bazin's affinity with Marcel is indirectly implied by the latter's notion of 'ontological exigency', which Angela Dalle Vacche opposes to Claude Mauriac's views on 'medium specificity', ${ }^{6}$ and Dudley Andrew provides in his biography of Bazin the setting for this plausible influence:

Only recently did I [Andrew] learn that Marcel and Bazin conducted a dialogue on cinematographic art, which was broadcast on the radio in 1948. This doesn't surprise me, as Marcel, a philosopher-playwright, like Sartre, who eagerly engaged the cinema, was also close to Bazin's friend Amédée Ayfre. ${ }^{7}$

Chaired by the poet Emmanuel Clancier, the roundtable discussion was in fact recorded at the International Encounters in Geneva around the necessity of renewal in the history of art. ${ }^{8}$ The theme of the talk was fully in line with

4 Bazin, 1952f, EC p. 830; Transl. Barnard, 2009, p. 133.

5 Sartre, 1946, p. 349.

6 Dalle Vacche, 2011, p. 150; Dalle Vacche references Jean Leirens' Le Cinéma et le temps (p. 96, 110). In a passage on Bergsonian durée in Diary of a Chambermaid (Robert Bresson, 1951), Leirens writes in a remarkably Bazinian fashion: 'This is without a doubt the only film to this day entirely dedicated to one of his paintings "from inside". Cinema here comes closer to painting, but in the domain where painting itself touches upon philosophy. I'm only talking about these comparisons, by the way, for the sake of convenience, since it would be vain to try to assign boundaries to the arts.' (Leirens, 1954, pp. 96-97).

7 Andrew, 2013, p. xxx. The exact broadcast Andrew references is from 20 September 1948 on Tribune de Paris, which featured a debate between Bazin, Marcel and Swiss zoologist Adolphe Portman. The debate was held in the context of the third Rencontres Internationales de Genève on contemporary art, to which both Marcel as a keynote speaker and Bazin contributed.

8 For a transcription of speeches and interviews, see Débats sur l'art contemporain. Tome 3. Neuchâtel: Les Éditions de la Baconnière (1948) < http://www.rencontres-int-geneve.ch/ volumes_pdf/rigo3.pdf $>$. 
a general demand for change after the Second World War, as Clancier points out in his introduction:

For years, people have suffered to such an extent that they all aspire change. It appears to me that each of us, unsatisfied with the miserable world around us, awaits and wishes, more or less, that this world would change. It seems to me that this desire, this wish for change, works equally well in relation to the artistic domain, as it does in the material or moral world. ${ }^{9}$

The conference in Geneva was organized to provide an interdisciplinary platform that fosters discussion on the role of contemporary art in post-war society. From a film perspective, it is cinema's particular form of the postwar art documentary that throws light on other, perhaps less popular art forms and thereby extend their social relevance. As Dalle Vacche writes: 'By associating the art documentary with an avant-garde orientation, Bazin theorized the relation between cinema and painting with the hope that art and cinema together could generate a sensibility more open to the value of spirituality in daily life. ${ }^{10}$ Precisely because of its popular character, film can bring about not only a renewal of artistic forms but also a revived popular interest in other arts. In 'The Art Documentary in the Postwar Period', Dalle Vacche continues:

\begin{abstract}
After 1945, in order to avoid paralyzing pessimism and endless revenge, the hope and need for human outreach called for a communal effort towards good will, despite the echoes, the mistakes, and the loose ends from the past. [...] Well aware of social struggles, religious divisions, and cultural boundaries, [Bazin] underlined cinema's universal and egalitarian address. After 1945, there was a feeling of urgency about peace on earth. [...] His hope was that well-made art documentaries could inspire audiences with new humanist, anti-anthropocentric values that would bring about a more tolerant, less greedy, and more self-critical mass culture. ${ }^{11}$
\end{abstract}

In fact, a closer examination of this particular debate, which I provide subsequently, clearly shows that Marcel, Portmann and Bazin share distinctive ideas on the fundamentally social character of cinema as well as the 
cross-influence between different art forms (literature, theater, painting, photography and cinema).

The topics discussed in this encounter resurface prominently in Bazin's later work, comprising a large amount of essays on cinema and other arts, most of them published after this debate. ${ }^{12}$ In fact, Bazin's general film historical orientation ('Cinema has yet to be invented!'3) aligns with the research interests of Portmann, the third member of this roundtable discussion and at the time zoology professor at the University of Basel, which was invested in the physiological prematurity of man (man is 'an animal born too early'). From this biological perspective, Portmann fully embraces the suggestion to renew the arts: 'I am absolutely certain that art has to transform itself, because art, from an aesthetic point of view, is a human function which is profoundly rooted in our being. ${ }^{14} \mathrm{~A}$ similar biological undercurrent is clearly present in Bazin's description of the interaction between cinema and painting, when he writes on Alain Resnais' Van Gogh (1948):

Like a lichen born from the symbiosis between the seaweed and the mushroom, the combination of cinema with painting here gives birth to a new aesthetic being; its ontology will perhaps enlighten us on some fundamental laws pertaining to the existence of painting and of cinema. ${ }^{15}$

As Dalle Vacche notes, underlining Bazin's adherence to a biological framework: 'The critic's scientific vocabulary, here, is crucial: the lichen is the paramount example of organic or intermedial symbiosis. ${ }^{16}$ From this frame of reference, Bazin's views on painting and cinema, more precisely the new aesthetics born from their combined ontology, coincide with an art critical discourse on the necessity or possibility for artistic forms to renew themselves. ${ }^{17}$ Marcel, for his part, initially looks at the avant-garde for fulfilling this desire for change rather than the general taste of the public, but later on, in his keynote lecture at that same conference, explicitly aligns himself with Bazin:

17 From this point of view, the biological resonances in the term 'ontogeny', Portman's primary research area, need not oppose the mechanism described by Joubert-Laurencin (Joubert-Laurencin, 2014, p. 21; see note ${ }_{5}$ Chapter II). 
It is extremely interesting to notice, as André Bazin very rightly said, that upholding the communication between art and the people is here an absolutely vital condition; it is a condition without which, given its financial conditions, cinema cannot even exist. It is for this reason that we can not only conceive of, but know, and point out works that are considered beautiful by the artists, in cinema, and works which can perfectly affect a popular audience. ${ }^{18}$

Bazin, who is always straightforward and univocal when it comes to this topic, states: 'cinema makes novels being read and popularizes theater plays. I position myself on this ground in a very worldly manner: cinema gives passport to the theater and the novel. ${ }^{\prime 19}$ Cinema, then, is able to bring out the socio-aesthetics of any art, in particular of painting which is, compared to literature and especially the theater, traditionally more removed from a broader audience. From this perspective, Andrew writes about Bazin's first defence of such a hybrid film, Rubens (Paul Haesaerts \& Henri Storck, 1948), that:

[...] the film operates both on the painting and on the spectator by forcing an aesthetic conjunction that tells us something about painting, about cinema, and about spectatorship. 'Who can complain of this?' [Bazin] innocently asks, pre-empting the scoffs he knew would come from art scholars. $^{20}$

One of those art scholars Bazin may have had in mind, according to Andrew, was the novelist and art theorist André Malraux, who occupies an ambivalent place in Bazin's views on the relation between cinema and painting. ${ }^{21}$ From an art historical point of view, Malraux adhered to what is often referred to as the 'Basic Story': a 'chronicle of technological progress'. ${ }^{22}$ This historical approach to the evolution of art forms entails that a painting made before the invention of the camera could not - stylistically speaking - be cinematographic: cinema might have influenced the history of painting, but this influence depends entirely on the actual invention of the camera. Initially, Bazin appears to adopt the idea that photography introduced an

18 Marcel, 1948, p. 202.

19 Bazin, 1948 [Radio broadcast].

20 Andrew, 2011, p. 155.

21 Bazin, 1945, EC p. 2555; Transl. Barnard, 2009, p. 7; on Bazin versus Malraux in relation to The Mystery of Picasso, see Andrew, 2011.

22 Bordwell, 1999, p. 27. 
abstraction in the development of modern painting (e.g. cubism, impressionism), stressing again its social function: 'Freed from the complex of resemblance, modern painters surrendered it to the people, who henceforth identified it with photography on the one hand and with the only kind of painting that applies itself to it on the other.'23 However, during the Geneva debate in 1948, as well as in his essays on painting and cinema specifically, his mention of myth, which I explain subsequently, proposes a more nuanced orientation that unties film aesthetics from technology.

\subsubsection{The Invention of Cinema Is a Myth}

While Marcel and Portmann appear to follow the Malrauxian argument, namely that the invention of photography has changed painting, ${ }^{24}$ Bazin takes a slightly different orientation. He elaborates on the particular influence of cinema on painting, as he sees the impressionist painter Edgar Degas (1834-1917), whose paintings from a historical perspective precede the invention of cinema, nevertheless mythically influenced by cinematographic realism:

It seems to me that if we go into the veritable influence or inter-influence of these arts more closely, we would be incited to take on a more flexible and more sceptical position, which would perhaps be this: namely that the influence, if really there is an influence of cinema on other arts and I indeed believe that it is blatant, among others in the novel and for photography on painting, if really there has been an influence, then this is not one from cause to effect. This would not be an influence through which painters at one point, seeing photographs, would have said to themselves: 'It is absurd to make portraits, I am going to do something else than portraits; I am going to make things that don't need to resemble

23 Bazin, 1945, EC p. 2556; Transl. Barnard, 2009, p. 7.

24 Portmann states: 'any art, the art of every day if you will, which was for a long time concerned with painting the portrait of citizens, that particular art has largely been transformed and replaced by photography. I'm thinking of illustrations in numerous books, scientific and biological ones, where photography has also largely rendered the activity of the artist almost useless, superfluous' (Portmann, 1948, n. pag.). In the Ontology article, Bazin appears to follow a similar line of thought in a footnote on book- and journal illustrations but reverses the order of causality: 'It would be interesting, from this perspective, to examine the rivalry in the illustrated press in the period 1890-1910 between photographic reportage, which was still in its infancy, and drawings. The latter in particular satisfied the Baroque need for the dramatic (consider Le Petit journal illustré). The sense of the photograph as a document emerged only gradually' (Bazin, 1945, EC p. 2555; Transl. Barnard, p. 11). 
nature anymore', that's not the case. Besides, historically speaking one finds that the history of photography is on the contrary a history of influences from painting on photography. Indeed, the first photographers tried hard to attempt to resemble painters. It is rather [...] an influence of the sensibility of the time period, of a profound need of that time period. In this manner, Degas for instance composes his paintings exactly like the end of a sequence on screen. Yet, cinema needed fifty years to recall the style of Degas on screen, and to construct its cinematographic framing totally naturally throughout the evolution of its language, like Degas made a painting. But this is because Degas was prophetic in his time and felt throughout this scientific and mechanistic nineteenth century the need to represent reality seized in some sort of simultaneously realist and dramatic synthesis, which cinema would find much later. So, if it is really there, we can speak of an influence of cinema on Degas, but not historical, since Degas precedes the cinema, but somehow of a myth of cinema, which was still subconscious at the time and which has influenced painting through an artist as sensible as Degas. ${ }^{25}$

According to Bazin, Degas' work is influenced by cinematographic realism, despite the historical anachronism: technically speaking, Degas could not have made cinema, yet his impressionist style might allude to more dynamic, cinematographic techniques like slow motions or fade-outs. Picking up the same theme, while rewriting his seminal essay 'The Myth of Total Cinema' in 1958, Bazin includes another reference to a particular myth, the myth of Icarus, to explain this ahistorical invention of film:

Of course, other examples of the convergence of research could be found in the history of technology and inventions, but we must distinguish those which are, precisely, the product of scientific advances and industrial (or military) needs from those which clearly precede these advances. The ancient myth of Icarus had to wait the internal combustion engine before descending from Plato's higher world, but this myth has been present in every human being since we began to observe birds. ${ }^{26}$

Bazin's mention of the myth of Icarus in this passage is anything but anecdotal: portrayed here as preceding the antiheroes of a technological invention, driven either by financial profit (the Lumière brothers and Thomas Edison) 
or scientific achievement (Etienne-Jules Marey and others), Bazin places Icarus among those 'fanatics, the maniacs, the disinterested pioneers' who had first imagined cinema. ${ }^{27}$ Cinema, of course, is an inherently mechanical art, but Bazin subordinates the technological inventions to the power of imagination: 'Cinema', he famously wrote, 'has yet to be invented!'28 With the myth of Icarus, Bazin not only solidifies the connection between the invention of film as imaginative rather than technological, but also nuances film histories that draw parallels between cinema and industrial (or military) needs. ${ }^{29}$ Bazin's parentheses bring us back to the historical context of the Geneva debate: the necessity for renewal in artistic forms implicitly requires a renewal of art theories and critical methodologies in which different media (cinema, painting, theater and literature, or poetry) mutually inform each other.

Again, a contemporary example illustrates this point. In his critically acclaimed animation film The Wind Rises (2013), Hayao Miyazaki blends artistic forms (more precisely animation film, literature and poetry) with human history on a mythical subject - human flight. The film tells the story of Jiro, a Japanese boy who dreams of flying airplanes, but his poor eyesight might keep him from realizing this dream. In the opening scene, he flies a small airplane over the city and countryside when, suddenly, his view is disturbed by a colossal, war-like flying machine. The goggles do not fit over his thick glasses and, cross-eyed, Jiro falls like Icarus back to earth. After an imaginary conversation with his mentor, the Italian aircraft designer Count Caproni, he realizes he can be an engineer instead of a pilot, as 'engineers turn dreams into reality'. Partly fictionalized from a novel by Hori Tatsuo, The Wind Has Risen (1936-1937), from which Miyazaki borrows the title (which, in turn, is a line from Paul Valéry's The Seaside

27 Ibid.

28 Ibid.; Transl. Barnard, 2009, p. 17.

29 See primarily Paul Virilio's War and Cinema: Logistics of Perception, in particular his chapter entitled 'Cinema Isn't I See, It's I Fly' in which he argues that 'Since the battlefield has always been a field of perception, the war machine appears to the military commander as an instrument of representation, comparable to the painter's palette and brush. [...] For men at war, the function of the weapon is the function of the eye. It is therefore quite understandable that, after 1914, the air arm's violent cinematic disruption of the space continuum, together with the lighting advances of military technology, should have literally exploded the old homogeneity of vision and replaced it with the heterogeneity of perceptual fields [emphasis in original]' (1989, p. 20). While industry usually shows itself particularly interested in warfare, the myth of Icarus in Bazin's writing posits a different view on the origins of cinema as combining a technological invention with an age-old dream of human flight. 
Cemetery $\left.3^{30}\right)$, the two protagonists of the film are based on historical figures: Italian aircraft designer Giovanni Battista Caproni (1886-1957), whose company built bombers for the Italian air force, and Jiro Horikoshi (1903-1982), known for designing the Mitsubishi A6M Zero fighter that was used in the Pearl Harbor attacks in 1940. Yet Caproni declares that 'Airplanes are not tools for war. They are not for making money. Airplanes are beautiful dreams. Cursed dreams... waiting for the sky to swallow them up.' Against the background of the Second World War, Miyazaki views the human desire for flight from an openly pacifist mind-set: where bombs only add weight to already bulky aircrafts, Jiro wants to design airplanes light as air. From this perspective of 'airplanes that don't return', Miyazaki questions the perversions of wartime all the while affirming the pacifist force of imagination, as Bazin does with his reference to Icarus. The film gradually merges Jiro's dreams with the harsh reality of a devastating war and personal loss, as his wife Naoko dies from tuberculosis. In the final sequence, Jiro meets Caproni again in his dream world, which is now a land covered with plane wrecks under a sky clouded by burning cities: 'it's the land of the dead.' Valéry's poem clearly guides the film from beginning to end: 'entre les tombes', despite such disasters, out of the clear blue sky 'le vent se lève' and Jiro must try to live!

By means of such intertextuality, then, specific artworks can adapt traditional themes or forms according to the 'sensibility of the time' and thereby answer to 'a profound need of that period'. Bazin's critical work is full of implicit intertextuality in which existing forms (myths, paintings, poetry) are given new meaning through their contemporary societal relevance. Rather than tipping into a dominantly formalist practice, ${ }^{31}$ however, this intertextuality in Bazin resonates with his distinctive cinephilia, which Serge Daney describes as follows: 'Loving cinema is loving this idea that we always make do with bodies that have already served, that have existed

30 As I will argue extensively later on, it is around this particular poem that Bazin constructs his critique of Le Monde du silence, ultimately making the formalist statement that accompanies his Myth argument (see Chapter IV - A MATTER OF FORM).

$3^{1}$ Intertextuality is a major sub-field in semiotic analysis which, following Julia Kristeva's initial account of the topic in 'Word, Dialogue and Novel' (1966), inspired Roland Barthes' (post-) structuralist statement that 'the text is a tissue of quotations' (Barthes, Roland. S/Z: An Essay. London: Cape (1974): p. 146). Barthes' publication is known to have put an end to the realist tradition in French criticism, which sought meaning in the mediating link between text and reality. Bazin's notion of 'recreation', however, could be seen as a realist alternative to, or even precursor of formalist intertextuality: film art is always an adaptation of reality, as much as writing criticism is always an adaptation of the original work of art. 
for others. ${ }^{32}$ From a realist point of view, cinema will always borrow forms: from other artworks but also, being itself a recreation of the world, from reality. In what follows, I want to analyze the apparent opposition between cinema and painting in accordance with his conviction that form and content in art can and should mutually inform each other: a particular painter's aesthetics had already been cinematic, and a painting's influence on film brings about a 'new aesthetic cosmology' to the screen.

\subsubsection{Bruegel Cinematographer}

By way of introduction to the extensive topic of cinema and painting in Bazin's body of work, I want to elaborate further on the myth of Icarus interpreted from a post-war perspective by examining a short, intertextual exercise offered by Bazin as an original entry into major ontological themes emerging from his discussion of cinema and painting. Let us then focus first on one painterly reference in his critique of the underwater exploratory documentary, The Silent World (Jacques-Yves Cousteau \& Louis Malle, 1956): not the impressionist style of Degas, but an implicit allusion to Pieter Bruegel the Elder's original interpretation of the Icarus myth in his Landscape with the Fall of Icarus from 1556 (Fig. 9). Bazin mentions it seemingly in passing but then uses the reference to construct his entire analysis of Cousteau's underwater universe. He writes:

In Bruegel's admirable painting, Icarus falling to the water in rustic indifference prefigures Cousteau and his companions diving into the green sea off some Mediterranean cliff, ignored by the farmer who works his field and takes them for swimmers. ${ }^{33}$

Here, again, Bazin sees a particular painting as prophetic of a film to come, exactly 300 years later. His description of the painting specifically pinpoints Bruegel's framing of the myth as fundamentally cinematographic: reduced to a detail, the tragedy of Icarus loses its prominence in the painting (his feet and some feathers are its only reminders). Moreover, Bruegel's masterpiece itself also offers a significantly original take on the classical myth, which 'loses its importance in face of this new conception of the cosmos' ${ }^{34}$ In fact,

34 De Tolnay, 1935, p. 28; Much has been written on Bruegel's interpretation of the Icarus myth; see, for example: Baldwin, 1986, pp. 101-114; Harries, 2002, pp. 93-103; De Vries, 2003, pp. 4-18. 
Bazin's description centers precisely on those elements of the painting that are originally and uniquely Bruegel's. The art historian Charles De Tolnay describes these as follows:

[T] here is no doubt that Bruegel would have resorted directly to the text [by Ovid], because he is the first to have represented the farmer at work, the shepherd on his staff, the fisherman with his line by hand. But he does this by reversing this exact text: rather than contemplating Icarus and Daedalus with astonishment, flying through the sky like gods, the carefree farmer continues his work, the shepherd turns his back to Icarus, stares fixedly at the emptiness ahead of him and the fisherman continues to be absorbed by his fishing; even the partridge, whose wings Ovid makes flap to eternally mock Daedalus, sits here immobile on its branch; even better, the ship next to which the catastrophe unfolds, clears off with its sails inflated towards the sun. ${ }^{35}$

Admittedly, Bazin's ekphrasis in the critique of The Silent World is rather brief and at first sight perhaps isolated from the painting/cinema question, but the fact that he reiterates the indifference of the peasant as well as the ignorance of Icarus' tragedy unfolding in the background strongly suggests that he picked up on a more general contemporary interest in the old master's work, which reinterprets the painting and the myth of Icarus from a modern perspective. ${ }^{36}$

Before and after Bazin, the myth of Icarus has been interpreted and reinterpreted through various art forms and from different historical perspectives. The resonances between the painting, Bazin's citation and its recent reiterations in fact allow us to find in Bruegel's work a particularly cinematographic ontology. In what follows, I will contextualize the brief citation as instrumental in what Bazin describes in his essays on painting and cinema in terms of a 'new cosmology of film', just like Bruegel's painting that, as his critics generally agree, offers a 'new conception of the cosmos' ${ }^{37}$ More specifically, I elaborate

Ibid., p. 29 .

36 Incidentally, as was the case with Miyazaki's The Wind Rises, Bazin's interpretation of this underwater documentary also relies explicitly on Paul Valéry's The Seaside Cemetery, to which I will return the final chapter (see 4.1.1 From Advertising to Poetry in Bazin). Though his analysis of The Silent World is brief, his film criticism can in this instance be read as an exercise in intertextuality or recreation, as I will call it later on: it illustrates his critical methodology in practice.

37 On Bruegel's 'cosmology', see for example: Alpers, 1983, in particular her analysis of the 'mapping impulse' in his paintings (pp. 133-136), which she relates back to the Alexandrian astronomer Claudius Ptolemy's ideas from Geography (145 AD). From a cinematic perspective, 


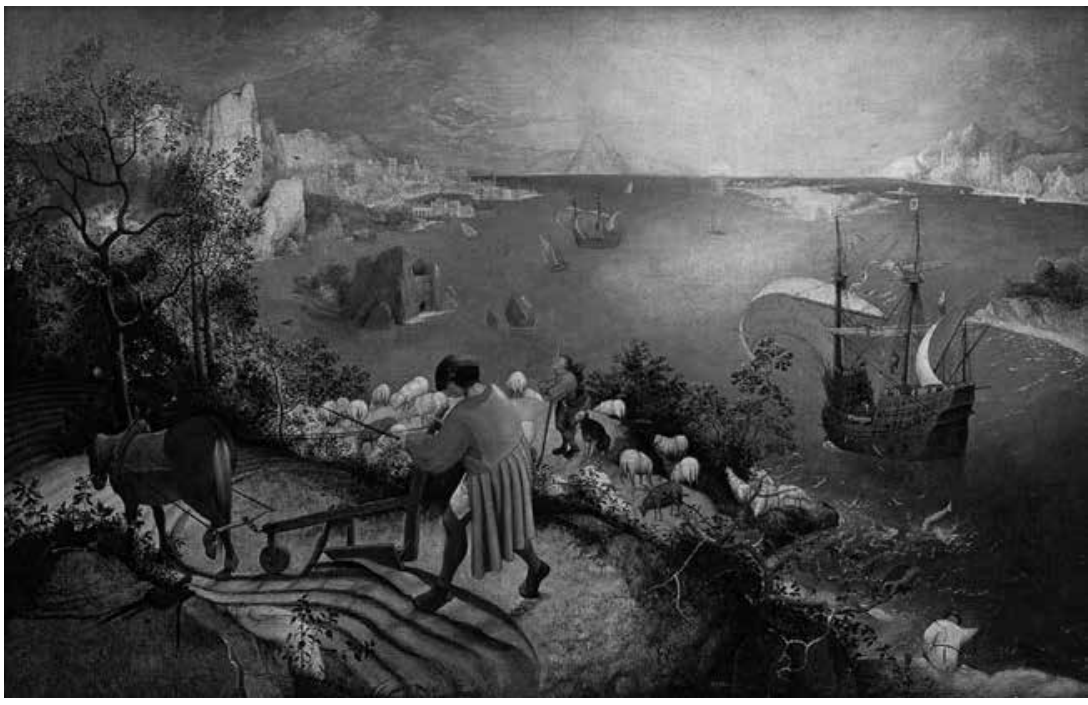

Fig. 9 Landscape with the Fall of Icarus, Pieter Bruegel the Elder (1556)

on Bazin's notion of the 'centrifugal screen' via a selection of references to both painting and poetry in his writing. First, however, I will follow up on the Icarian analogy in the 'Myth' essay, by situating Bazin's reference to Bruegel alongside W.H. Auden within a tradition of twentieth-century anti-war poetry. In this manner, I maintain that such an anachronistic influence between painting and cinema - suggesting that Bruegel would have painted according to a particularly cinematographic aesthetic - is not exceptional in Bazin's views on art history and indeed supports his notion of myth.

Tom Conley in Cartographic Cinema first looks at Bazin's Icarus anecdote to construct his general argument: 'to each film its map' (Conley, 2007, p. 5), and in a later chapter also refers to the work of Ptolemy in a specific discussion of maps as they appear in The Gladiator (Ridley Scott, 2002). Ptolemy's work is indeed intriguing when it comes to the 'new cosmology' or worldview in cinema. In his astronomical study the Almagest (150AD), Ptolemy describes the apparent motion of the stars and planets based on observations and lays the foundations for a cosmology that holds earth at the center of the universe. His calculations fit within ancient Greek physics that intended to 'save the appearances [sozein ta phainomena]', as the French mathematician Pierre Duhem (1861-1916) famously wrote (Sōzein ta phainomena: essai sur la notion de théorie physique de Platon a Galilée, 1905). With the Copernican revolution in the sixteenth century, the Ptolemaic cosmological model was replaced by a heliocentric worldview. It seems to me that Bazin might be dipping into these issues when he writes at the outset of his Ontology essay that it is a photographic image's primordial function to 'save being by appearance [sauver l'être par l'apparence]' (1945, EC p. 2555); in any case, the notion of 'cosmology' clearly guides his analysis of Vincent van Gogh's aesthetics transformed on screen, discussed later on in this chapter. 


\subsection{3. 'How Everything Turns Away': Icarus as Anti-War Statement}

During the course of the twentieth century, Bruegel's version of the Icarus myth gained remarkable attention, following the initiative of the AngloAmerican poet W.H. Auden's Musée des Beaux-Arts, written in December 1938 during a visit to the Royal Museum of Fine Arts in Brussels and published the following year. Auden begins his poem with the more general approach of the Old Masters to the theme of human suffering in an always apathetic setting, and then picks up the Bruegelian indifference in the Icarus painting:

About suffering they were never wrong,

The Old Masters; how well, they understood

Its human position; how it takes place

While someone else is eating or opening a window or just walking dully along;

How, when the aged are reverently, passionately waiting

For the miraculous birth, there always must be

Children who did not specially want it to happen, skating

On a pond at the edge of the wood:

They never forgot

That even the dreadful martyrdom must run its course

Anyhow in a corner, some untidy spot

Where the dogs go on with their doggy life and the torturer's horse

Scratches its innocent behind on a tree.

In Breughel's Icarus, for instance: how everything turns away

Quite leisurely from the disaster; the ploughman may

Have heard the splash, the forsaken cry,

But for him it was not an important failure; the sun shone

As it had to on the white legs disappearing into the green

Water; and the expensive delicate ship that must have seen

Something amazing, a boy falling out of the sky,

Had somewhere to get to and sailed calmly on. ${ }^{38}$

Auden reinterprets the painting within the zeitgeist of the period, shaded by social apathy and anxiety following the Great War, as a wakeup call. As Judith Bernstock argues: 'twentieth century artists generally revive ancient myths as part of their search for a common ground accessible to all.'39 More specifically, Alexander Nemerov argues that '[the painting] 
is Bruegel's aesthetic lesson to other artists of the 1930 and 1940 os about the incorporation of social content', ${ }^{40}$ and so the Icarian theme provides a platform for universal anti-war statements. Following Auden, several poets and painters have repeated the reference to Bruegel's Icarus, giving it an enduring significance in relation to the contemporary concerns of a century marked by wartime: 'in both the original work and modern versions, life continues - the fall of Icarus fails to disturb the harmony between man and nature. ${ }^{41}$ The shared interpretation of Bruegel's Icarus as an address to social apathy in wartime implicitly builds on a lesser-known etching by the painter, which portrays the fall of Icarus in a much more dramatic setting. In Man of War Sailing to the Right; Above, the Fall of Icarus (1561-1562), Daedalus is there, witnessing his son's tragedy as it happens, and instead of 'calmly sailing on', the ship is caught in a stormy ocean (Fig. 10). The title of this etching deliberately frames the mythic tragedy from the point of view of war: in Bruegel's time, the man-of-war was a vehicle of war, armed with canons and driven by sails rather than oars, which were the usual propellers of combat ships like galleys, for example. The ship is in fact identical to the one in Landscape with the Fall of Icarus: by the look of the wind in its sails, we know now that this ship is going to war. Where in Bruegel's etching, then, Icarus' tragedy is dramatically aligned with the implied sufferings of wartime, his subsequent painting depicts war, in Auden's words, from a 'human position; how it takes place while someone else is eating or opening a window or just walking dully along'. These recent reiterations of Bruegel's interpretation of Icarus indeed raise pertinent questions regarding the social impact of documenting epic tragedies (like war, or a little boy falling from the sky), while elsewhere life goes on. As the old proverb, often associated with Bruegel's painting, has it: 'no plough stands still just because a man dies. ${ }^{.22}$

Tackling the same issues at stake, the surrealist writer André Breton (18961966) includes in First Papers of Surrealism (1942) a cut-out that reinterprets, again, Bruegel's Icarus in the context of the Second World War; this time, with a

40 Nemerov, 2005, p. 804; Nemerov reads Musée des Beaux-Arts against the backdrop of Journey to a War (published in 1939), in which Auden and Christopher Isherwood recount their travels to China during the Sino-Japanese war (1937-1945) as they witnessed an air raid on the city of Hankow: 'Aerial machines, squinting upwards, innocent victims - these experiences so fresh in Auden's mind must have given the fate of Bruegel's falling boy a contemporary resonance' (Ibid., p. 785). 41 Bernstock, 1993, p. 179; For instance, incorporating the myth of Icarus on war in painting, there are Felice Casorati (Icarus, 1936), Henri Matisse (Icare, 1943), Pablo Picasso (La Chute d'Icare, 1958), Anselm Kiefer (Icarus, March Sand, 1981); from the side of the poets, William Carlos Williams (Landscape with the Fall of Icarus, 1960), Anne Sexton (To a Friend Whose Work Has Come to Triumph, 1962).

42 Glück, 1936, p. 24. 
particular reference to a news report on excessive bombings on Düsseldorf(Fig. 11). This print is featured in the section 'On the Survival of Certain Myths and on Some Other Myths in Growth or Formation',43 and clearly positions Bruegel's Icarus in a new light. Breton radically changes the original composition: he eliminates the sky, the sun, the ocean and the field, and in doing so urges the viewer to combine all the characters involved into one diagonal strip, with the city at the top. Anna Blume describes Breton's composition as follows:

Breton cuts out this detail in the shape of the ploughman's foot. By doing this Breton leads us to wonder what the relationship might be between bombs at Dusseldorf, the single step of the ploughman, and the falling Icarus. ${ }^{44}$

'Detail: Bruegel', the print's subheading reads. By aligning one detail (Icarus falling) with another (the ploughman's foot), Breton pushes the analogy of the image-fait as fait divers: a devastating war takes the form of an unimportant, almost banal instant, the footstep, and vice versa. Considering the other textual element in the composition, Breton furthermore explicitly frames the tragedy of Icarus in an address to the role of news reporting media: 'Düsseldorf has been bombed yesterday for the fiftieth time. (The Newspapers).' In Bruegel's etching, his painting, as well as Breton's interpretation of it, meaning is derived from the formal organization of the tableaus: a tragedy of mythical proportions, Icarus' death or bombings on Düsseldorf, is presented as a detail, taking up no more, no less space (hence: importance) than the fisherman, the ploughman, the setting sun, or even - another detail, barely visible - Auden's untidy spot, the corpse in the bushes on the left. 45

The interplay between front-page news and faits divers brings me to another, more contemporary interpretation of Icarus. In his documentary film Tableau avec chutes (1997), Claudio Pazienza captures the implications of Bruegel's message well: dressed in a red shirt, like the dutiful ploughman,

43 Breton and Duchamp, 1942, n. pag.

44 See Anna Blume's full discussion of this cut-out in 'In the Wake of Production: A Study of Bruegel's Landscape with the Fall of Icarus' (1995, pp. 240-241).

45 Following W.H. Auden, many poets of the twentieth century have interpreted Bruegel's painting. In relation to the corpse, see specifically Jan Kal's 'The Fall of Icarus [De valvan Icarus]' (1974), which I cited at the outset of this chapter. It was the art historian De Tolnay, also cited earlier in this chapter, who in the 1930s discovered the corpse hidden on the left of the frame. Kal's reference to Michelangelo Antonioni's Blow Up (1966) makes sense and points again to the masterpiece's inherent cinematographic aesthetics: as in the film, an unclear detail blown out of proportion makes for an entirely new interpretation of an apparently undisturbed scene. 


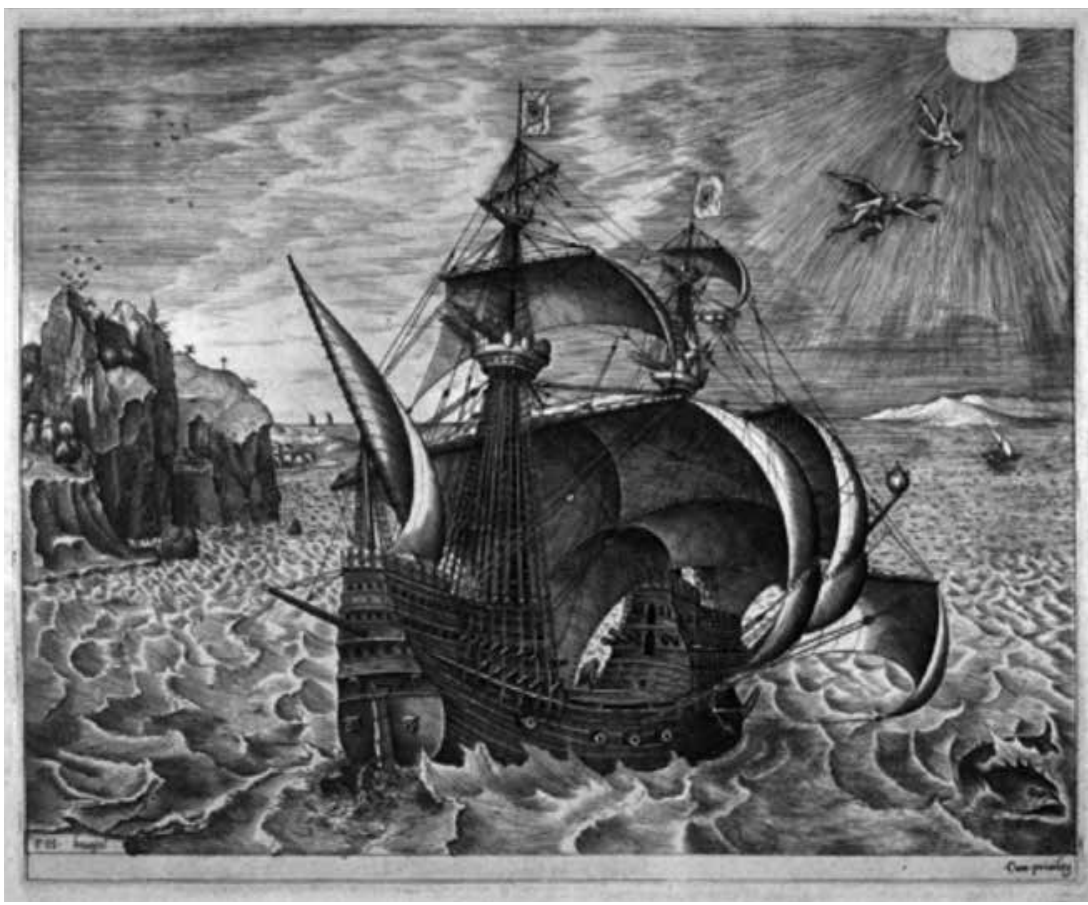

Fig. 10 Man of War Sailing to the Right; Above, the Fall of Icarus, Pieter Bruegel the Elder (1561-1562)

and with a print of Landscape with the Fall of Icarus and a camera in hand, Pazienza sets out to ask the Belgians (his parents, the dentist, professors, the prime minister, his neighbors, those on social welfare) what they see in this painting: 'Icarus swims, from both sides of the linguistic border.' Most people do not notice Icarus, others take him for a bather or, perhaps, someone who is drowning. 'But this happens here as well', a Flemish woman remarks: 'Sometimes people are just looking, and something happens and they don't do anything either.' By setting the documentary against the background of several nationwide revolts in the nineties, ${ }^{46}$ Pazienza explores the social and political involvement of a people in specific historical events: Bruegel's painting of Icarus poses the question concerning 'the distance between the one who is looking and that which is being looked at'. Why do certain events

46 For instance, large-scale strikes against educational reform; the child abuse cases of Julie and Melissa, An and Eefje, and Sabine and Letitia; the nationwide 'white march' following the dismissal of their investigating magistrate Jean-Marc Connerotte: these current affairs put the finger on injustice and flaws in the judicial system that mobilized the Belgians to speak out against the government. 


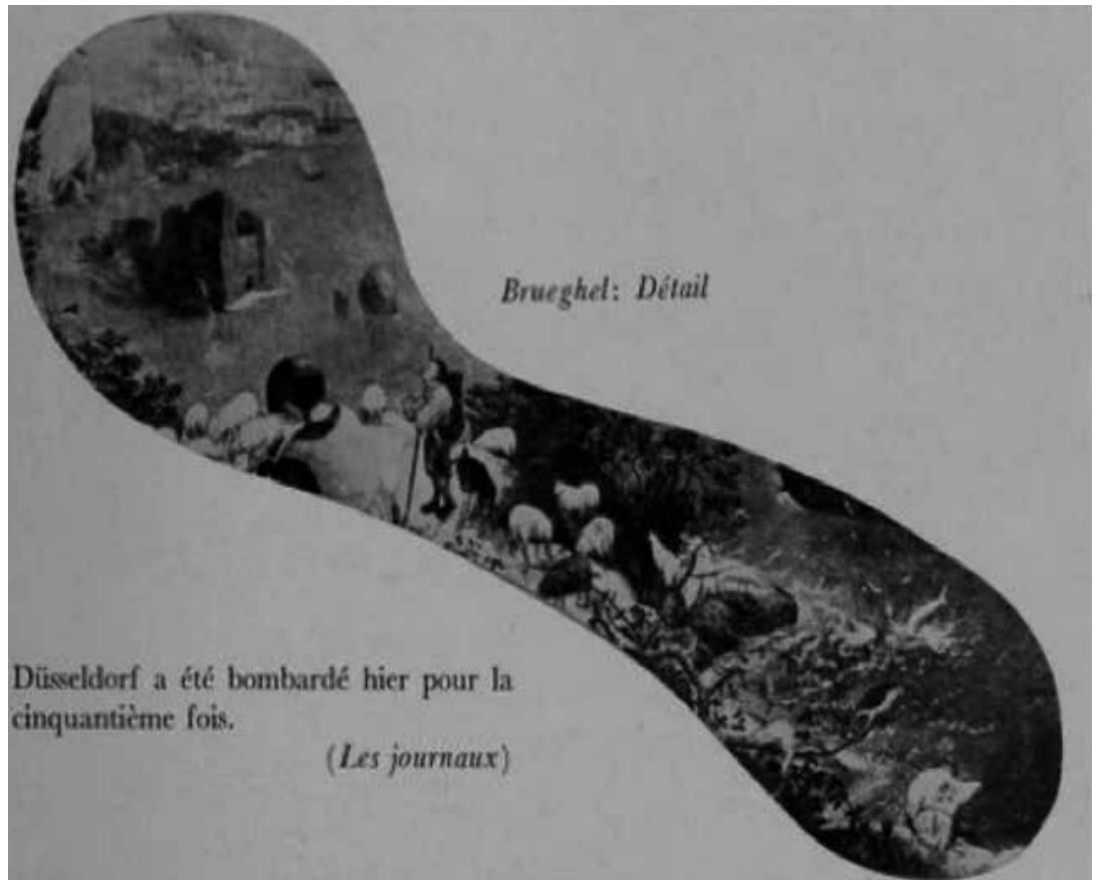

Fig. 11 Cutout by André Breton (1942)

make us instantly drop whatever we are doing, while others leave us cold; and what role do images play in our closeness to tragedies that, to take on a French phrase, ne nous regardent pas? Against social apathy, Pazienza's interpretation of Icarus follows the centrifugal principle of human reality: the documentary as 'a hymn to man with his feet anchored on earth'. In Bazin's words: rather than a succession of front-page events, cinema is 'a printing press of reality'. ${ }^{4}$

To sum up, there are two theoretical implications proceeding from Bazin's short reference to Landscape with the Fall of Icarus that both concern the relation between cinema and painting in Bazin's oeuvre. First, it acknowledges that the spatial qualities of a particular sixteenth-century painting prefigure the cosmology of the cinema screen, which supports his thesis of film invention being a myth. Secondly, it is important to note that the fall of Icarus is the only mythical theme painted by Bruegel, whose usual subjects were either biblical or everyday sceneries, and that he interprets the myth in such a way that it decreases the mythical proportions of its traditional treatment: in short, and using Bazin's terminology, he interprets 
a fundamentally painterly and centripetal subject in a centrifugal manner. In fact, the phrase in Auden that most pertinently describes this indifference - he writes: 'how everything turns away' - already carries the kernels of Bazin's invention of the image-fait in post-war neo-realist cinema. Bazin's references are in that sense fully in line with the twentieth-century revived interest in the Icarus myth, as the prevalence of painting in his oeuvre finds itself especially concerned with cinematographic realism. We clearly see that, unlike the so-called 'pregnant instant' of painting, its realism derives from the ontological equality of events, which is inherently cinematographic. In Bruegel's Icarus, everything turns away from the center of the drama: all the characters and even the sheep in the foreground have their backs turned to Icarus. In his extensive studies on cinema and painting, Bazin further develops this view in terms of a 'centrifugal screen' of cinema, which I will discuss in more detail below.

\subsection{Cinema and Painting}

Bazin's affirmation of cinema as the art of reality, discussed extensively in the previous chapter, lays the foundations for what he calls the 'centrifugal' force of cinema. As argued, integral realism entails that on film, as in reality, not a single moment prevails over another, because there is no prescribed ontological preference of one moment over the other: cinema and reality are ultimately equal. In his essays on cinema and painting, Bazin further develops the Newtonian references as he opposes the screen of cinema to the 'centripetal frame' of painting. Where he employed a biological metaphor to indicate the symbiosis between painting and cinema in films on art, his writing on Vincent van Gogh presents a comparable interaction in the metaphor he borrows from Newtonian mechanics, more precisely in his description of the cinema screen as centrifugal:

Each painting is defined in relation to a frame, at least virtual, which carves in some way the hole of the painter into the world, reserves in the natural macrocosm the microcosm of the artist. This comes back to noticing that the frame of the painting is oriented from the exterior towards the interior, that it defines a heterogeneous centripetal space in the background which it surrounds. [...] In this manner, whereas the frame orients the closed off space of the painting towards the interior, 
the screen on the contrary diffuses the space of the cinematographic image into infinity: it is centrifugal. ${ }^{48}$

In his juxtaposition of cinema and painting, Bazin here alludes to Dutch physicist and mathematician Christiaan Huygens (1629-1695), who first proposed the idea of a vis centrifuga: 'Heaviness is a tendency to fall. [...] Thus, when a heavy body is suspended from a string, then the string is pulled, since the heavy body tends to fall away along the lines of the string with an accelerated motion of this sort. ${ }^{49}$ However, this centrifugal force, Isaac Newton reminds us later, does not exist on its own; it is instead a reactionary force. In Definition 5 , he replies to Huygens and develops his theory of centripetal force:

Centripetal force is the force by which bodies are drawn from all sides, are impelled, or in any way tend, toward some point as to a centre.

One force of this kind is gravity, by which bodies tend toward the centre of the earth [...]

A stone whirled in a sling endeavours to leave the hand that is whirling it, and by its endeavour it stretches the string, doing so the more strongly the more swiftly it revolves; and as soon as it is released, it flies away. The force opposed to that endeavour, that is, the force by which the sling continually draws the stone back toward the hand and keeps it in orbit, I call centripetal, since it is directed toward the hand as toward the centre of an orbit. [emphasis in original $]^{5^{\circ}}$

Thus, the most characteristic of centripetal forces is gravity, precisely this force that cinema in its analogy with human flight desires to escape: freed from the burden of subjectivity bound by a representational frame, cinema abides by an opposing force, that of an off-screen, out of frame. From this perspective, Bazin clearly starts off affirming that both art forms are anything but equal:

[...] despite an apparent similarity with the frame of a painting, the screen maintains essentially different relationships with the image. The cinema screen is not a frame, but a mask, it does not serve to show, but to reserve, to isolate, to choose..$^{1}$ 
In his extensive enquiry into the relation between painting and cinema, Bazin pinpoints their fundamentally different ontologies as respectively centripetal and centrifugal. In principle, the world of a painter for Bazin is not that of the filmmaker: 'The infinity of a landscape by Jean-BaptisteCamille Corot is an infinity that is internal to the existence of the painting; it cannot merge with the infinity of nature without (and this would be absurd) acting as its substitute. $5^{2}$ Where the existence of a painting depends first on the canvas and the frame, the existence of film relies primarily on a pre-existing reality: the image is a fact [fait], 'a fragment of raw reality's3 that exists somewhere in reality, even if it is absent from the screen. Hence, according to Bazin, the screen is a mask rather than a frame: with a close-up of a pair of shoes on screen, for example, we know that these shoes exist in a larger setting off-screen, whereas nothing proves, strictly speaking, that the same is true for Vincent van Gogh's famous Pair of Shoes (1888). ${ }^{54}$

To explain this principle in more detail, Bazin introduces a definition of cinema that references a sequence from Jean Cocteau's The Blood of a Poet (1930). In the second episode of the film, the poet and a statue are stuck in a room, from which there is only one exit: the mirror. Against common sense, the statue tells him: 'Indeed, but you have written that one does enter mirrors, and still you don't believe it! Try it!' After diving into the mirror, he floats (or flies) through a boundless space. He then arrives in the hallway of the Hotel of Dramatic Lunacies with a series of closed doors that, despite his firm efforts, remain closed. So he looks through the keyhole, and sees and hears a variety of things: a slow-motion execution of a Mexican in rewind,

52 Ibid.

53 Bazin, 1948c, EC p. 358; Transl. Barnard, 2009, p. 241.

54 That is to say, nothing proves that these shoes as painted objects have an off-screen setting. When it comes to the artwork's ontological grounding in the world, see Martin Heidegger's analysis of this specific painting in 'The Origin of the Work of Art' (1935-1936): 'There is nothing surrounding this pair of peasant shoes in or to which they might belong, only an undefined space. [...] A pair of peasant shoes and nothing more. And yet.' (p. 14) This 'and yet' is then followed by a series of associations through which Heidegger senses in these shoes 'the silent call of the earth' (ibid.). Tempering Heidegger's interpretation of the shoes, Meyer Schapiro's famous answer states: 'Alas for him, the philosopher has indeed deceived himself. [...] He has indeed "imagined everything and projected it into the painting". He has experienced both too little and too much in his contact with the work. [...]. Heidegger would still have missed an important aspect of the painting: the artist's presence in the work' ('A Note on Heidegger and Van Gogh.' In: Theory and Philosophy of Art: Style, Artist and Society. New York: George Braziller (1998): pp. 138-139). With key topics like the artist's subjectivity, the frame and the painting's extension into the world, the contribution that Bazin's analysis of painting versus film could bring to this discussion is significant, but it exceeds the scope of this footnote. 
a Chinese shadow play, a little girl's flying classes, a hermaphrodite, etc. From this sequence, Bazin concludes that:

One will at least admit that everything we see in cinema is perceived as real, i.e. as participating in a uniformly stretched out space, in other words: in a universe. One of the most correct definitions of cinema is the one from Jean Cocteau: 'reality seen through a keyhole'. What the keyhole hides from us does not seize to exist itself outside our visual field. ${ }^{55}$

The episode of The Blood of a Poet condenses two aspects that Bazin considers fundamentally cinematographic, or centrifugal: the screen as a mirror and as a mask [un cache]. That which is not visible on screen (or in the mirror and through the keyhole) still exists in reality. To think otherwise would be like assuming that nothing exists behind a door because it is closed. From a similar perspective, the doorknob, in a text on Italian neo-realism, becomes the opposite of cinema's centrifugal image:

Once again, this is the opposite of 'doorknob' mise-en-scene, in which the colour of paint, the grime at hand height, the shininess of the metal and the wear on the latch are perfectly useless facts, concrete parasites of the abstraction which are best disposed of. ${ }^{5}$

Being the opposite of the shot [plan], which I have previously discussed as fundamentally alien to Bazin's views on integral realism, the centrifugal image gives way to and assumes what lies beyond the screen, whereas the painterly image thanks its existence to the surface of a centripetal canvas. Cocteau's poet embodies this paradigm shift: where a mirror implies the superficial gaze of Narcissus, the surface here gives way to a threedimensional world. Bazin's studies on cinema and painting develop alongside a comparable shift in perspective, in which the surface of a painting is transformed into a universe that takes on the spatial properties of lived, three-dimensional perception. Thus, whereas Bazin initially opposes cinema and painting, this dichotomy in his work is always overruled by an interest in their shared aesthetics. To explain these shared aesthetics, I will now turn to his essays on art documentaries with filmed paintings, first Picasso and then Van Gogh, in which Bazin labels the formal transformation of painting on film as a 'geographic temporality'. 


\subsubsection{Two Revolutions on Film: Geographic Temporality}

When a painting is filmed, what we see on screen is no longer a painted image but a spatial as well as a temporal metamorphosis of the original composition. Traditionally, when it comes to depicting space, a painting is tied to its canvas; and with expressing time, it is stuck with one single frame. From an explicitly Bergsonian perspective, Bazin reinterprets this relation between form and content in his analysis of Henri-Georges Clouzot's The Mystery of Picasso (1956), which shows Picasso at work, in terms of 'pictorial duration': 'What The Mystery of Picasso reveals is not what we already know, the duration of creation, but this duration that might be an integral part of the work itself, a supplementary dimension, stupidly ignored at the finishing stage. ${ }^{57}$ From this point of view, Bazin differentiates between 'the picture [le tableau]' and 'painting [la peinture]': 'We see clearly that already the notion of the picture [le tableau] is subordinated here to the more integral notion of painting [la peinture] of which the picture is but a moment. ${ }^{5}{ }^{8}$ Clouzot films Picasso at work by placing the camera alternately either behind his back or behind the canvas, capturing the strokes as they appear through the cloth. Against the time constraints of depleting film stock, the process of painting unfolds its dramatic suspense in real time:

Because, in the end, every trait, every stain of colour appears - appearing is the right word - rigorously unforeseeably. This unpredictability supposes, inversely, that the whole of the composition cannot be explained by its parts. This is so much true that the entire principle of the film as spectacle itself, more precisely its 'suspense', lies in this waiting and this continuous surprise. Each trait of Picasso is a creation that entails another, not in the way that a cause implies an effect but as life generates life. 59

Each trait, each moment is ontologically equal to the previous stroke and therefore the images that appear on screen arise from mutations of previous forms (Fig. 12-13): 'The spectacle as such is then a fascination by the appearance of forms, free and in nascent state. ${ }^{\prime 60}$ Content is literally induced by form: 'the fish becomes a bird and the bird becomes wildlife. ${ }^{61}$ When 

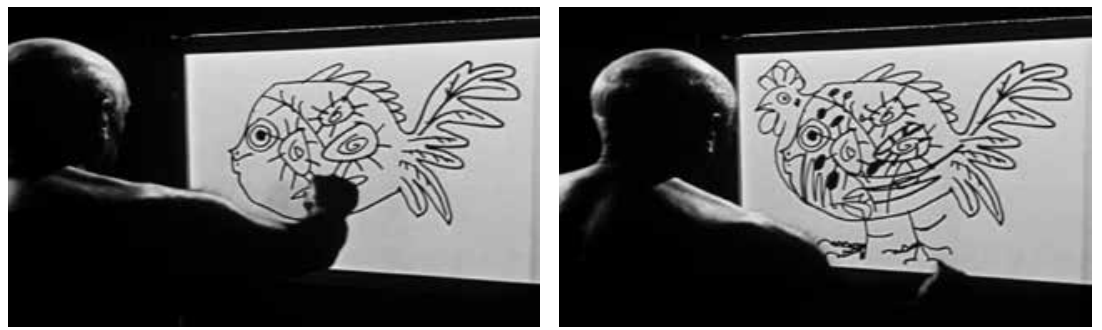

Fig. 12-13 A fish becomes a bird in The Picasso Mystery

filmed, Picasso's image is transformed into a temporal, essentially cinematic sequence: there is no pregnant moment, no single frame, but painting in action twenty-four frames/second.

While The Mystery of Picasso comprises an essentially temporal revolution in the hybrid form of painting and cinema, this was, according to Bazin, preceded by an initially spatial revolution in Alain Resnais' Van Gogh (1948), in which 'everything settles as if painting would truly become soluble in the duration only after having undergone a mutation of its spatial structures under the action of cinema, ${ }^{62}$ As argued, Clouzot challenges the painterly moment suprême by transforming each moment in painting into a cinematic image-fait; Resnais, as I will demonstrate now, turns the centripetal frame centrifugal. Resnais' short documentary on Van Gogh is entirely composed of shots inside paintings: the camera's gaze wanders from painting to painting as if the painted world of Van Gogh became real. In Bazin's words:

Thanks to the cinema, the 'world' of a painter is not merely a metaphor anymore, 'entering in his universe', the privilege of a sensible and cultivated spectator, the pictorial imaginary has become the reality of our perception. ${ }^{63}$

Resnais attains this assimilation of the imaginary and real perception by ignoring the frames surrounding the paintings. The house in Nuenen, the city of Paris, the yellow house in Arles, the bedroom and the café, the courtyard in the asylum, and a field with crows: the camera combines all these places into one geographical space rather than separating them off in different paintings.

62 Bazin, 1949b, EC p. 525 .

63 Ibid. 
[...] the sequence of a film gives it a unity in time that is horizontal and, so to speak, geographical, whereas time in a painting, so far as the notion applies, develops geologically and in depth. ${ }^{64}$

This sort of directional inversion, from a geological temporality to a geographical temporality, occurs each time the camera 'enters' painting: under the influence of the camera, Van Gogh's universe is now turned centrifugal.

In his text on The Mystery of Picasso, an art documentary by a director mostly known for his suspenseful films, Bazin already emphasized the dramatic potential of painting in film, and indeed the cinematic interest in painting often exceeds a purely documentary purpose. Examples of films about paintings abound in film history, yet when it comes to dramatizing a still picture, Dario Argento's rather graphic, violent thriller The Stendhal Syndrome (1996) offers a particularly intriguing case of 'entering the world' of a painter, in this case Rembrandt. The opening sequence, incidentally the first time an Italian film production had used CGI, clearly addresses the dramatic interaction between painting and cinema. For reasons she does not yet remember, a police inspector on a rape and murder case, Anna, visits the Uffizi gallery in Florence on what looks like an ordinary busy day. Once inside, a montage sequence accompanies close-ups of paintings with sounds as they appear to come to life: impalements and crossbows in the Battle of San Romano by Paolo Uccello (1436-1440), suddenly interrupted by a tourist taking its picture. In the Sala del Botticelli, there are Venus (1486) carried by the Zephyr wind and La Primavera (1481-1482). Anna longs to touch the flowers surrounding the feet of the three graces, but she is stopped by the alarm as if an invisible screen reminds her that it is a painting, that there is a surface. She then enters the Gallery of Maps, where maps and globes surround the space. Caravaggio's Medusa (1595-1598) makes her dizzy: the paintings are everywhere, on the walls and ceiling. Anna is about to lose her sense of orientation at the very moment when the sequence culminates in Bruegel's Icarus. Noticing his legs still peeking above the surface of the water, she falls and busts her lip, dives underwater into the painting, floats back to the surface and regains consciousness on the floor in the museum. She is then left with a noticeable bloodstain on her white shirt, which features in the subsequent scenes as a temporal disruption proper to painting, and in doing so, offers a novel take on what Bazin calls geographic temporality. 
Anna has the Stendhal syndrome, a psychosomatic condition that causes certain people to become dizzy, hallucinate or faint under the overwhelming effect of art and great beauty. ${ }^{65}$ After the fall in Florence, she cannot remember who she is, and why she happens to be in that city; with a bloodstained shirt, she hurries back to the hotel room that matches the key in her purse. Her name is written on a prescription for sleeping pills: she is Anna Manni, a police inspector from Rome. After taking her pills, while resting on her bed, it happens again: this time, she is caught up in a reproduction of Rembrandt van Rijn's Nightwatch (1642). ${ }^{66}$ The camera cuts from drums to feet, faces to arms and accompanied with the soundtrack of a crime scene, the paint fades as Anna enters into a murder scene in the streets of Rome (Fig. 14-19). There, a rapist and serial killer left the police with yet another case for Anna and her colleagues to solve; it now becomes clear that she will have to travel to Florence to catch the murderer. Even though the crime scene develops as if Anna's Stendhal syndrome was nothing but a bad dream, at best a flash-forward offering a glimpse of her future manhunt in Florence, the bloodstain on her shirt is still there in Rome; or, the stain was already there. As is the case often in painting, when a single figure is presented multiple times in the picture plane to portray a chronological succession of events within a single frame, Anna's bloodstain here functions as a refracted temporal element when she walks inside the painting and literally invades the frame. Once she enters the universe of the painter, the narrative takes a fascinating turn: whereas, logically, one could think that either the opening scene in Florence was a prophetic dream, or the sequence inside the Nightwatch had been a flashback, the bloodstain on Anna's shirt prevents us from adopting one or the other interpretation. Much like in Resnais' Van Gogh, Argento's close-ups transform the space of painting into the real streets of Rome, but the geological temporality of painting somehow affects the horizontal temporal unity of cinema.

65 The Stendhal syndrome is named after the French writer Stendhal who had first reported it after his visit to the Basilica of Santa Croce in 1817. In his diary, Stendhal describes the experience as follows: 'Absorbed in contemplation of sublime beauty, I saw it up close, I touched it so to speak. I had arrived to that point of emotion where celestial sensations offered by the fine arts meet passionate sentiments. Leaving the Santa Croce, my heart was pounding, phrenic nerves as it is called in Berlin. I was emptied of life, I was walking with the fear of falling.' (Stendhal, 1862. Rome, Naples et Florence. Paris: Gallimard, 1987: p. 272).

66 The interplay between cinema and painting that Argento incites here has been claimed more recently by Peter Greenaway in his series of animated paintings: using light projections combined with sound installations, Greenaway's first revision was Rembrandt's Nightwatch at the Rijksmuseum in Amsterdam, the result of which is very close to Argento's. 

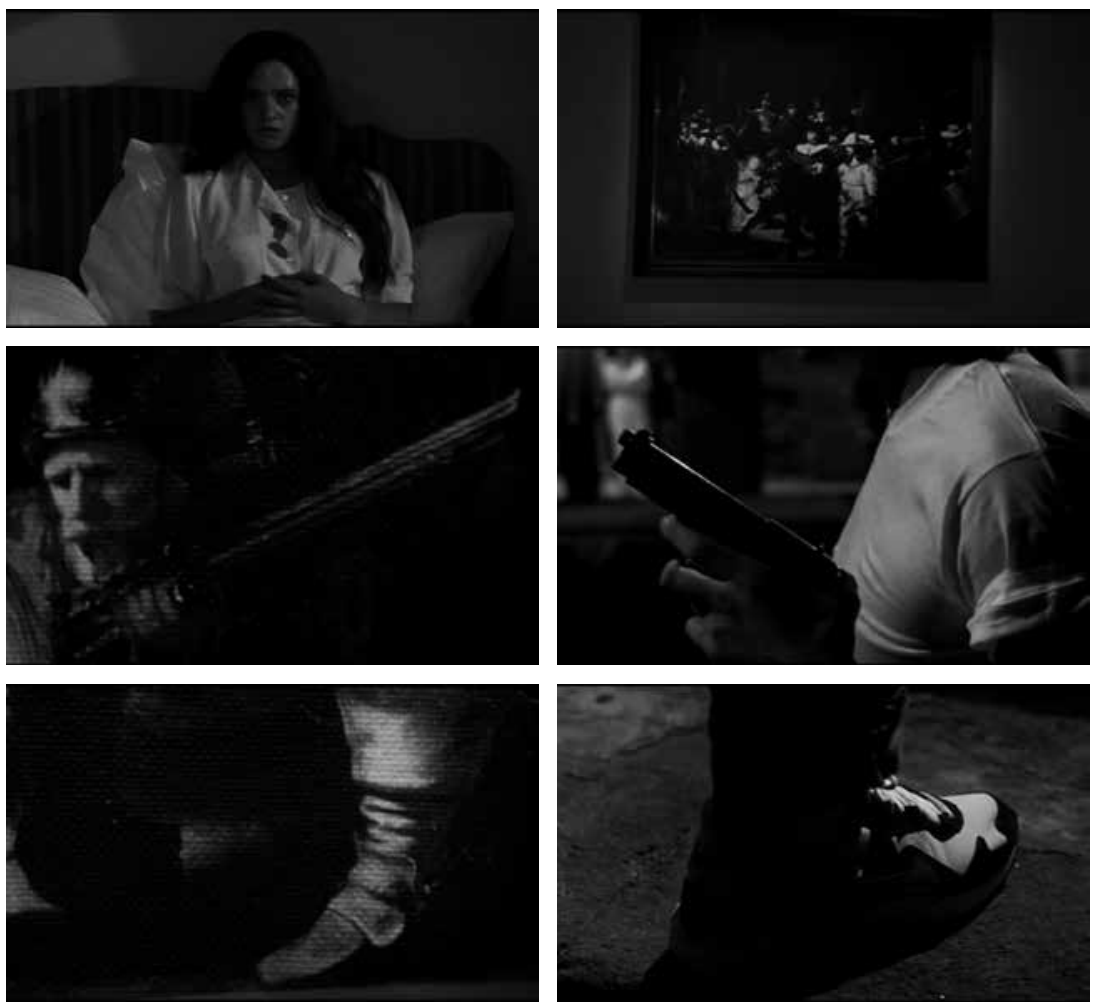

Fig. 14-19 Nightwatch and geographic temporality

In fact, the discourse of Anna's stain in The Stendhal Syndrome is reminiscent of a remark made by Bazin in his critique of Van Gogh, which further explains this interaction between geological and geographical temporality in terms of space. When filming the Starry Night (1989), he writes, Resnais refused to simultaneously show the threefold repetition of the sun but chose instead to reorganize the space on screen following a 'new aesthetic cosmology':

Van Gogh's landscape spreads nature to substitute for three suns at the same time, if it pleases the master to assemble them in a sequence of images that turned irrefutably in this new aesthetic cosmology. ${ }^{67}$

Bazin's description of a 'new cosmology', an idea that, as I have established previously, had also been used by critics to describe Bruegel's Icarus, draws 

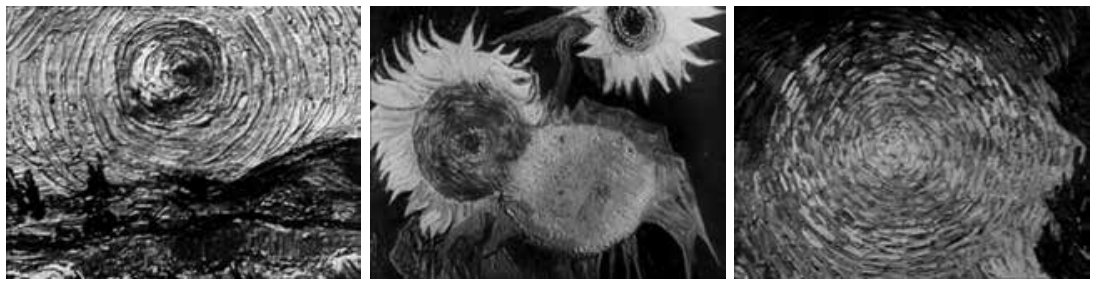

Fig. 20-22 Stars and sunflowers in Van Gogh

parallels between Van Gogh's suns and his sunflowers. Anna's bloodstain in The Stendhal Syndrome can thus be understood as a new aesthetic cosmology, in which the spatial-temporal qualities of the screen and the frame are altered under the combined influence of painting on film, and vice versa. The three suns to which Bazin refers are in fact stars, but behind this seemingly careless mistake there lies an array of literary references, which also inform Resnais' particular sequence in the film (Fig. 20-22). These references align Van Gogh's approach to nature (in other words, his aesthetics) with his sunflowers, as well as his questioned insanity. Bazin's commentary on Van Gogh, which I discuss below, indeed proves that he had carefully examined two seminal studies on the painter: Georges Bataille's 'Sacrificial Mutilation and the Severed Ear of Vincent van Gogh' (1930) and Antonin Artaud's 'Van Gogh: The Man Suicided by Society' (1947). From these perspectives, I want to analyze the centrifugal ontology of film by close-reading a particular reference in Bazin to Van Gogh's cut-off ear.

\subsection{Case Study: Van Gogh's Ear}

If Bazin's writing on painting and film start off by distinguishing both art forms, it is ultimately their combined aesthetics that interests him the most: a painted detail in Bruegel that turns a painting filmic, or a filmed painting that renders the pictorial frame centrifugal. In other words, it is cinema's recreation of painting that interests him, just as it is cinema's recreation of reality on which his concept of realism is built. One final reference to Van Gogh in Bazin specifically concerns this connection between art and reality: the particular image of Vincent van Gogh's dismembered ear. Bazin briefly mentions it in his discussion of Resnais' art documentary: 'Van Gogh's cut off ear exists somewhere in this world, which inevitably beseeches us. ${ }^{\prime 68}$ 
Though this reference appears trivial, it lends itself as a particularly fruitful case for studying the effect of film on painting, as it deals explicitly with the transparency of the screen versus the opacity of the canvas. Tracing this recreation in Bazin, furthermore, positions his examination of painting and film into an intricate patchwork of contemporary critiques, from Georges Bataille (1879-1962) to Antonin Artaud (1896-1948) and Fernand Deligny (1913-1996), on the effect of art on reality.

We all know the story of the artist's ear: on the advent of Christmas 1888, Van Gogh cut off his left ear lobe with a razor, supposedly following an argument with his colleague painter Paul Gaugin (1848-1903) with whom he maintained a tumultuous friendship. Van Gogh had been waiting for him in Arles, hoping to start an artist community in the yellow house. But when Gaugin announced his premature departure, Van Gogh supposedly lost his mind. Gaugin's version of the story was that Van Gogh had threatened him with the razor, after which he cut off his own ear in a flare of madness and brought it to a prostitute named Rachel later that evening, with a request to 'keep this object carefully' ${ }^{69}$ Gaugin's portrayal of his friend as a madman who turned against his person, however, is contested: '[Gaugin's] behaviour during their final days together and in the later attempts to vindicate himself through condemning Vincent were hardly those of a friend. ${ }^{70}$ In what follows, I close-read the critiques of Alain Resnais' Van Gogh (1948) as well as Vincente Minnelli's Lust for Life (1956), in which Bazin develops his notion of a new cosmology of film and thereby aligns himself with Antonin Artaud's conception of 'mythic reality' and Georges Bataille's studies on the painter's supposed madness. Both Bataille and Artaud reject the idea that Van Gogh was mad: the fight with Gaugin was also an aesthetic struggle and, hence, the cutting incident must relate to the painter's artistic vision. Bazin adopts their ideas in his discussion of these two films: again, he sees in the symbiosis of painting with cinema their shared aesthetics, which he qualifies as myth.

\subsubsection{Mythic Reality Becomes Flesh}

The lineage to Artaud's study of Van Gogh is previously established by Dudley Andrew, who points out that these ideas must have reached Bazin via French educator Fernand Deligny, known for his involvement in special

69 Lubin, 1972, p. 156.

70 Ibid., p. 179. 
needs education..$^{11}$ Andrew writes that Bazin and Deligny shared an office at Travail et culture and that:

Deligny was moved to assemble an imaginary dialogue between Van Gogh's letters and Antonin Artaud's book on Van Gogh's suicide when Artaud died in 1948. This occurred just as [Chris] Marker's friend Resnais was bringing to a close his film on the artist. There must have been innumerable discussions among these men since Bazin had found Deligny an apartment in the same building..$^{2}$

Artaud's main argument in 'Van Gogh: The Man Suicided by Society' (1947) is that Van Gogh's self-mutilation (e.g. burning his hand to catch the attention of his cousin and love interest Kee, or slicing off his ear lobe) evade the standard label of madness: 'As for the cooked hand, that is heroism pure and simple; as for the severed ear, that is straightforward logic. ${ }^{73}$ Ultimately, Artaud recognizes the suicide almost as a socially organized crime: as the title of the article reads, Van Gogh was 'suicided', murdered by society:

Van Gogh could have found enough of the infinite to last his whole life if the brutish consciousness of the masses had not wanted to appropriate it to nourish their own orgies, which have never had anything to do with painting or poetry. ${ }^{74}$

Thus, Artaud understands the ear mutilation as a logical consequence of a painter whose relation with the world has been continually denied as impaired by a people in their attempt to safeguard a collective 'sick consciousness'.

What interests me most in the connection between Bazin and Artaud on Van Gogh is the fact that Artaud frames the disagreement between Van Gogh and Gaugin, generally understood to be the cause of the ear incident, in terms of a conflicting conception of myth and reality. On the occasion of

71 Andrew, 2011, p. 162; Thus, it is from a pedagogical context that Bazin may have been drawn to discussing Van Gogh in relation to cinema. Pedagogy was one of Bazin's major points of interest before cinema, see for example 'L'Enseignement primaire supérieur, suivi de Péguy et les instituteurs.' Rencontres, No. 3 (20/07/1941), which he wrote under the pseudonym André Basselin. I return to the pedagogical undertone of Bazin's critical work in the concluding section of this chapter.

72 Andrew, 2011, p. 162.

73 Artaud, 1947, p. 486.

74 Ibid., pp. 510-511. 
a Van Gogh exhibition at the Musée de l'Orangerie in Paris, Artaud writes that the relationship between both painters was troubled by:

[...] a profound human division between the two natures of Van Gogh and Gaugin.

I believe that Gaugin thought that the artist must look for symbol, for myth, must enlarge the things of life to the magnitude of myth, whereas Van Gogh thought that one must know how to deduce myth from the most ordinary things of life.

In which I think he was bloody well right.

For reality is frighteningly superior to all fiction, all fable, all divinity, all surreality.

All you need is the genius to know how to interpret it,

Which no painter before poor Van Gogh had done, which no painter will ever do again, for I believe that this time,

Today, in fact,

Right now,

In this month of February 1947,

Reality itself,

The myth of reality, mythic reality itself, is in the process of becoming flesh. ${ }^{75}$

Thus, the supposed madness at the root of the ear incident and ultimately Van Gogh's suicide fundamentally relate to what Artaud calls 'mythic reality'. Where Gaugin painted from 'imagination', Van Gogh 'neither ignored nature, nor slavishly followed it'. ${ }^{6}$ Instead, he found that in reality, fiction and myth 'become flesh', a view Bazin must have considered was related to his notion of integral realism. Furthermore, as was the case with the reference to Bruegel's treatment of the Icarus myth, Artaud emphasizes the contemporary value of myth in combination with a turn to the everyday, 'the ordinary things of life'.

The connection between Bazin and Artaud on the topic of Van Gogh finds solid support almost a decade later in the critique of Vincente Minelli's Lust for Life (1956). Firstly, Bazin criticizes the overly biographic attempt to provide reasons for Van Gogh's supposed madness (a fight with Gaugin? missing his brother?):

The point is not to explain to us why Van Gogh was 'mad' and what the necessary connection was between this madness and his predilection 
for yellow, for example, but to bring us closer to this point of spiritual incandescence where the transmutation will be made sensible to us through its radiance..$^{77}$

Like Artaud, Bazin deemphasizes the relation between madness and the preference for a certain aesthetic, but rather accepts it as a justification for Van Gogh's painterly soundness. Secondly, Artaud asserts that Van Gogh's paintings permanently alter reality:

these flowers of bronze gold are painted; they are painted as sunflowers and nothing more, but in order to understand a sunflower in nature, one must go back to Van Gogh, just as to understand a storm in nature, a stormy sky, a field in nature, it is henceforth impossible not to go back to Van Gogh. ${ }^{7}$

Artaud's argument here comes close to the transformative potential of art, which Bazin conceptualizes as the asymptote of reality, discussed in the previous chapter. ${ }^{79}$ Bazin indeed repeats this line of thought in a critique of Minelli's all too painterly characters:

This is to make nature resemble art, as [Oscar] Wilde said, which is true only a posteriori. Van Gogh has transformed our vision of sunflowers but before he had painted them, sunflowers were not yet 'Van Goghs. ${ }^{80}$

Here, again, Bazin's reading of Lust for Life takes on remarkable similarities with Artaud's argument that 'even external nature, with her climates, her tides, and her equinoctial storms cannot, after Van Gogh's stay upon earth,

77 Bazin, 1957a, EC p. 2107.

78 Artaud, 1947, pp. 503-503.

79 See also Joubert-Laurencin, who elaborates on the anti-mimetic formula by Oscar Wilde, namely that 'nature imitates art', and Alain Roger's notion of 'artialisation', i.e. the intervention of art in nature via both 'modelling [modélisation]' and 'anticipation': 'Furthermore, if ontological realism, following the advice of Rohmer (great meteorological filmmaker, of four seasons), dictates that "art is in the model", in the sense that it is in the landscape, and the anticipation [artialisation] of Alain Roger says that art offers its models to landscape, then cinema is the double trigger: on the one hand, as a machine of automatic reproduction, it captures the schemes offered by the other arts, on the other hand, as art, it offers them to nature.' Joubert-Laurencin, 2014, pp. 78-79.

80 Bazin, 1957a, EC p. 2107. 
maintain the same gravitation, ${ }^{81}$ Both Bazin and Artaud suggest that Van Gogh's paintings are not the symptoms of a man's madness but rather that their 'cosmology' altogether changes the commonplace conception of reality.

It is not coincidental, then, that Bazin finds in Resnais' documentary on Van Gogh, which would have initiated Artaud and Bazin's shared interest in the painter, the kernel for his notion of a new cosmology of film. Based on the sequence of the triple suns, and in combination with a posteriori sunflower transformation, Bazin's reading follows the film's commentary, which states: 'It's not for nothing that sunflowers are called suns [Ce n'est pas pour rien que les tournesols s'appellent des soleils].' This line from the film is an almost literal adaptation from a passage from 'Sacrificial Mutilation and the Severed Ear of Vincent van Gogh', written in 1930 by Georges Bataille:

in order to show the importance and the development of Van Gogh's obsession, it is necessary to link suns with sunflowers [...]. This flower is also simply known (in French) by the name 'the sun'; in the history of painting it is linked with the name of Van Gogh. ${ }^{82}$

The commentary here relates the sunflowers to a new worldview, a connection Bazin readily incorporates in his critique. Incidentally, the link between the sun and sunflowers, in addition to a posteriori influence of art on reality that guides both Artaud and Bazin's texts, equally leans on an argument put forth by Bataille in a later essay entitled 'Van Gogh as Prometheus' (1937):

Given the forgoing, it must be said that after the night of December '88, when, in the house to which it came, his ear met a faith which remains

81 Artaud, 1947, p. 484.

The recurring allusion to cosmology in Bazin and Artaud's treatment of Van Gogh's aesthetics, furthermore, brings to mind a series of more recent astronomical studies of The Starry Night in particular. See, for example, Whitney, 1988, pp. 351-362; and Boime, 1984, pp. 86-103. Based on meteorological records, Whitney writes that 'all the elements of the sky in Starry Night were on view through van Gogh's window at one point or another that spring. They were not all in view at the same time, but we need to give up the notion that he painted the scene as a snapshot. I think he assembled his own sky from impressions gathered over an interval of a month or so' (p. 358). From his side, Boime connects the swirly stars in the painting to popular drawings of spiral nebulae dating from 1845, which illustrated the popular publications of the French writer and astronomer Camille Flammarion (1842-1925, p. 89). These two studies suggest that the Starry Night was not, as is often assumed, painted from memory (and therefore believed to be a concession to Gaugin's aesthetics) but rather that it is in fact painted from nature and thus an inherently realist work.

82 Bataille, 1930, p. 260. 
unknown (one can only dimly imagine the laughter and discomfort which preceded some unknown decision), Van Gogh began to give to the sun a meaning which it had not yet had. ${ }^{83}$

Bataille furthermore relates Van Gogh's cosmology to the sunflowers, the suicide and the ear: 'How can we ignore the chain of knots which so surely links ear, asylum, sun, the feast and death?' ${ }^{84}$ And so, rather than affirming the supposed madness of Van Gogh, Bataille and after him Artaud and Bazin all relate the self-mutilation, via the sunflowers, to his cosmological intelligence. Just as Artaud views the ear injury as 'straightforward logic', so too does Bazin ground the new cosmology of film as a logical consequence of the ontological difference between painting and film, and he does this, as I suggest throughout the following pages, via the ear reference.

\subsubsection{Self-Portraits with Bandaged Ear: Mirror and Mask}

Just as Artaud and Bataille frame their studies on Van Gogh against his assumed insanity, Bazin also indirectly presents the centrifugal foundations of cinema as straightforward logic. When he writes, 'Van Gogh's cut-off ear exists somewhere in this world, which inevitably beseeches us', ${ }^{85}$ Bazin is making a strong statement about the ontology of film as well as the influence of art on reality. I will now juxtapose the ear covered with a bandage in the series of self-portraits painted by Van Gogh after the incident to the eerie phenomenon of the missing ear in two films: the particular scene from Minelli's Lust for Life that moved Bazin to write about the ear, and a sequence from David Lynch's Blue Velvet (1986), possibly the most referenced and original cinematic treatment of Van Gogh's severed ear.

In January 1889, Van Gogh completed a series of self-portraits in which he painted himself with a bandaged ear: having severed his left ear, both portraits 'being mirror images, [...] show the bandage on the right side'. ${ }^{86}$ In his depiction of the incident, Minelli places Van Gogh literally in front of a mirror (Fig. 23): after a short pause, he then moves out of frame and cuts off his lobe (Fig. 24), we hear him screaming, after which he returns to the mirror with one ear too few. Minelli copies the spatial organization of Van

83 Bataille, 1937, p. 498; Transl. Michelson, 1986, p. 59.

84 Ibid., p. 499; Transl. Michelson, 1986, pp. 59-6o.

85 Bazin, 1949b, EC p. 525 .

86 Lubin, 1972, p. 156. 
Gogh's mirrored portraits, showing the right ear damaged (rather than, in Van Gogh's reality, the left). In doing so, this particular scene combines the mirror ${ }^{87}$ and the mask - two images that, as shown previously in the reference to Cocteau's The Blood of a Poet, summarize the spatial principles of the centrifugal screen. In Bazin's words: 'The cinema screen is not a frame, but a mask; it does not serve to show, but to reserve, to isolate, to choose. ${ }^{.88} \mathrm{In}$ the cinema, we know that when Van Gogh moves out of the frame, especially when he screams off-screen, that he is still in the same room; upon his return, we know for sure that his cut-off ear did not mysteriously vanish, despite its absence on screen. This very principle can be used for dramatic purposes. In Blue Velvet, Van Gogh's ear is the catalyst for a detective adventure into a dark and sickening world of sexual violence and abuse. On his way home from a visit to his father at the hospital, Jeffrey discovers an ear, which he wraps in a brown paper bag and brings to the police (Fig. 25): 'That's a human ear, alright!' says the police inspector. And because an ear does not exist without a corresponding body, there is no doubt that somewhere in Lumberton a man must be missing his ear. Even though Jeffrey was explicitly asked not to inquire after the ongoing investigation, he starts his own with the help of the detective's daughter Sandy. They find out that the ear belongs to Don, the husband of a nightclub singer Dorothy, mother of little Donny. A dangerous man named Frank keeps Dorothy's husband and their young child hostage, while forcing her to partake in all sorts of abusive practices: 'Stay alive, baby. Do it for Van Gogh', she is told. So, where Van Gogh cut off his own ear for assumed reasons, either 'to sacrifice himself, to kill a

87 In 'Theater and cinema' (1951c), Bazin most explicitly develops the metaphor of the screen as a mirror: 'The nineteenth century, with its objective visual and sound reproduction technologies, introduced a new category of images. Their relationship with the reality at their source needs to be rigorously defined. [...] Cinema's efficacy can also be found in its ontology. It is false to state that the movie screen is completely powerless to place us in the presence of an actor. It does so like a mirror (which, we can all agree, conveys the presence of the person it reflects) - a mirror whose reflection is at a variance with the person whose image is imprinted on its silvering' (EC p. 734; Transl. Barnard, 2009, p. 185). In a subsequent part of this research I will return briefly to the relation between cinema and theater to address the notion of presence in relation to three-dimensionality (see 4.2.1 From a Realist Perspective: 'The Imaginary Image). When Bazin writes that 'just as footlights and scenery in the theater serve to mark the contrast between it and the real world so, by its surrounding frame, a painting is separated off [...] from reality as such [...]' (Bazin, 1952d, EC p. 2569; Transl. Gray, 2005, p. 165), he compares the difference between painting and cinema alongside its opposition with the theater stage. However, just as his interest ultimately lies in the combined aesthetics in filmed painting, so too is his embrace of 3-D largely based on a symbiotic relation between cinema and theater.

88 Bazin, 1949b, EC p. 525 . 
part of his own body, and turn his friend Gaugin into a murderer, ${ }^{89}$ the husband's ear is used as leverage. The final scene in Dorothy's apartment actually shows Don, tied to a chair with the left ear cut off (Fig. 26), unlike Minelli's version. Despite the real possibility that these are merely continuity errors, the comparison with the series of self-portraits as mirror images is noteworthy: Minelli's camera appears to have entered Van Gogh's universe, whereas Lynch seems to depict Van Gogh's lived reality.

To assume, as Bazin does, that Van Gogh's cut-off ear 'exists somewhere in this world', even if one might not see or find it, is indeed not far-fetched an idea: there is no need to bring in neurological evidence for the experience of phantom limbs to understand the beseeching relation between a particular ear and the person to which it belongs, regardless of its visible presence. In Lust for Life, we do not see the actual deed, but we hear his scream off-screen; similarly, in Van Gogh's self-portrait, the ear is covered with a bandage. In fact, the ear in these particular portraits is missing, obviously, in two senses: first from a logical point of view, they were painted after the mutilation, and secondly from an ontological perspective, there is no evidence that a painter would in fact have included a layer depicting an ear underneath the bandage. In this manner, the comprehension of the screen as a mask conceptualizes the major ontological difference between painting and cinema. With painting, there is no reason to assume that that which is invisible on the surface (e.g. out of frame, covered either by clothing, hair or, in this case, a bandage) is actually there or has been painted somewhere: logically speaking, there is nothing to mask, because the canvas shows all there is in paint. On film, on the contrary, it would be completely irrational, madness even, to see the image on screen as separate from the reality to which it refers: cinema and reality, Bazin affirms, are thick as thieves in the same way that we know sensibly that an ear covered by a hat or a bandage exists somewhere, regardless of the fact that it remains hidden to us.

The existence of Van Gogh's ear off-screen, somewhere in the world, perfectly aligns itself with the centrifugal principles of cinema, which comprise a temporal and spatial ontological equality between cinema and reality. Where the painterly canvas is traditionally pure surface, the cinema screen is a surface much like the skin: as Paul Valéry wrote, 'the skin is that which is the most profound in us. $9^{90}$ From this point of view, Bazin's

89 Lubin, 1972, p. 176.

90 Paul Valéry, cited in Timothée Gerardin's short but insightful essay, entitled 'A la surface' (Le Rotor*, No. 10 [Accessed: 20/02/2015]), in which he takes Valéry's citation as a starting point 


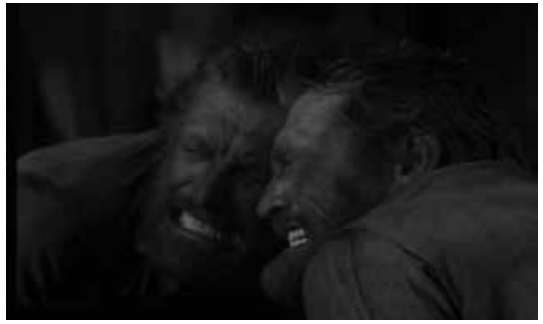

Fig. 23 Van Gogh's mirrored portrait

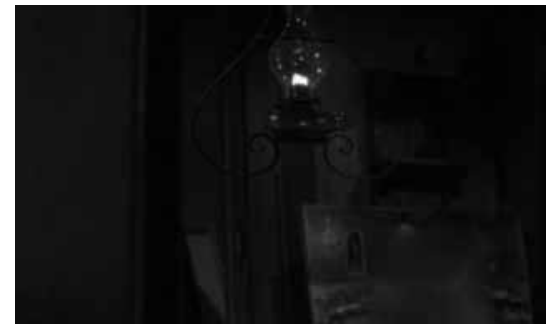

Fig. 24 Off-screen mask

fascination with surgical images and X-rays on screen further explains this necessary link between the centrifugal image on screen and the universe beneath the skin: 'To view the X-ray of a beating heart in the cinema is already a marvel', ${ }^{91}$ he writes, reaffirming his praise of science films in which 'cinema reveals that which no other procedure of investigation, not even the eye, can perceive'. ${ }^{2}$ Van Gogh's ear, then, materializes the centrifugal ontology of cinema: mythic reality becomes flesh.

\subsection{Recreation: The Language of Film}

The arguments and analyses presented in this chapter are built almost exclusively on intertextual references, or recreations: from Bruegel's Icarus, W.H. Auden and Cousteau, to including more contemporary interpretations of the same image - from Van Gogh, to Artaud and Bataille, Resnais, Minelli and Lynch. ${ }^{93}$ This method, in itself heuristic and perhaps too serendipitous for certain academic discourses, nevertheless works towards our understanding of fundamental concepts in Bazin's thinking. In fact, recreation can be seen as instrumental in Bazin's practice as a film critic: in one of his essays on painting and cinema, he writes, 'there is also a certain type of literary

to discuss Bazin's ontology argument, more precisely the mummy complex as well as the shroud of Turin, from the perspective of a 'profondeur à fleur de peau'. As I will argue later on in this book, Valéry's views on depth and surface, in particular his poem The Seaside Cemetery, will prove instrumental, if not indispensable, to understanding integral realism as a reformulation of the conventional notions of form and content (see Chapter IV - A MATTER OF FORM).

91 Bazin, 1956a, EC p. 1874; Transl. Andrew, 2014, p. 120.

92 Bazin, 1947c, EC p. 309; Transl. Herman, 2000, p. 145.

93 Parts of this conclusion are also published in the conference proceedings of Encontro Fernand Deligny, Rio de Janeiro (August 2016), as 'Can you 'Ear me? Lautoportrait de Vincent Van Gogh vu par Bazin et Deligny', Cadernos Deligny, Vol.1, No.1 (2018): pp. 225-238. 

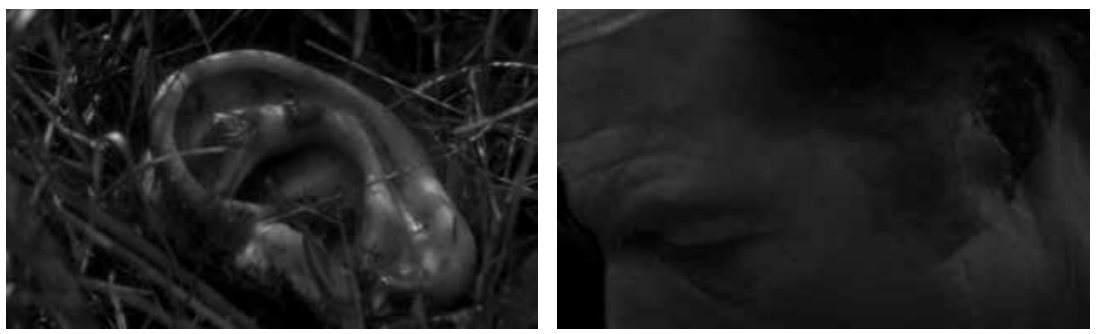

Fig. 25-26 Van Gogh's ear in Blue Velvet

criticism which is likewise a re-creation - Baudelaire on Delacroix, Valéry on Baudelaire, Malraux on Greco'. ${ }^{94}$ Just as cinema in these case studies recreates and therefore transforms painting into a new aesthetic cosmology, so too does art criticism engage in a process of semantic intertextuality. Bazin's usage of the word 're-creation', furthermore, can be linked to his more general expression of cinema as a 'recreation of the world in its own image':95 the intertextuality between cinema and painting equally applies to the semantics of cinema as the art of reality - in other words, the language of film.

To explain this, let me return in conclusion to the professional context for Bazin's interest in Van Gogh, referenced earlier in this chapter: his time at Travail et culture in the late forties, where he worked in popular education shoulder to shoulder with the experimental pedagogue Fernand Deligny (1913-1996). ${ }^{96}$ During this time, Deligny was undertaking a documentary project with socially excluded, delinquent teenagers under the provisional title Children Without Future? To facilitate their reintegration into society, Deligny resorted to cameras, because 'language', he writes, 'intoxicates them and fails them whenever they need to make themselves heard'. ${ }^{97}$ Though their collaboration at the time was brief, decades later Deligny still expresses a deep affinity for Bazin's work:

94 Bazin, 1952d, EC p. 2570; Transl. Gray, 2005, p. 169.

95 Bazin, 1946/1958, EC p. 2559; Transl. Barnard, 2009, p. 17.

96 Andrew, 2013, p. 140. Bazin and Deligny met in 1946 on the occasion of a film screening, organized by Deligny who was then regional director at Travail et culture for the region NordPas-de-Calais. Starting in 1948, Bazin and Deligny met on a regular basis, as Deligny had been transferred to Paris where he now worked with Bazin for the same organization. For several years, they shared an office, lived in the same building, and found themselves personally involved with the reintegration of the then young delinquent François Truffaut.

97 Deligny, 1955, p. 414. 
It's a happy coincidence that you brought along the Cahiers du cinéma with Bazin, Bazin's articles. In it, I happen to stumble on a citation from Malraux: 'the possibility of linking man and the world through other means than language'. That's it, this is what cinema is for him. For Malraux, cinema is the possibility of linking man to the world by other means than language. And here again, this really reassured me! With my stories about images I'm not that donnish after all, I'm not alone... There is, the way I see it, a tradition which was interrupted by psychoanalysis and other ways of thinking for which language is... everything. ${ }^{98}$

Deligny's aversion to language-based ways of thinking grows when, in the seventies, he develops successful therapies for mute autistic children: unable to communicate through language and therefore left untreated in existing psychiatric programs, these children used cameras to connect meaningfully with the world around them. In this manner, he describes Bazin's interrupted tradition as 'ethical': for Deligny, the Cahiers du cinéma presented 'a momentum that pushed us to run our heads against the limits of language'. ${ }^{99}$ Bazin's realist semantics, I will explain subsequently, occurs through what he called a 'language of objects' rather than a system of signs: a radically concrete and direct process of signification, through recreation.

Bazin's realist approach to film language becomes most tangible in an anecdote that deals implicitly with the photographic recreation of a painting. During the time at Travail et culture, a photograph was taken probably by Chris Marker, who was then Bazin's secretary, or Janine Chartier, his girlfriend at that time and future wife (Fig. 28). ${ }^{100}$ In it, we see Bazin hard at work in his office, making a phone call. From his biography, we know that the years working in that office were among Bazin's happiest years; ${ }^{101}$ and despite his rather tormented expression in the picture, the photograph in fact appears to be a practical joke, a tongue-in-cheek reference to Vincent van Gogh's self-portrait with bandaged ear (Fig. 29). Juxtaposed, the photograph indeed reveals striking similarities with Van Gogh's self-portrait: both men wear a heavy coat, where one would expect a shirt in the office. In the background, a poster announcing the program for the month of April corresponds with the Japanese print in the portrait, while the cupboard in Bazin's office aligns with the window frame of Van Gogh. The pitchforked 
hook of the telephone is reminiscent of the painter's easel. Bazin's bandage does not cover his ear but takes the place of Van Gogh's fur hat - the telephone, in turn, replaces both in form and composition the bandage of the painter. The replacement of the bandage with a telephone solidifies the discussion of Van Gogh's ear off-screen, discussed at length earlier in this chapter: provided that Bazin's phone is connected, his ear - invisible on screen - extends to a reality outside of the picture frame. ${ }^{102}$

This playful instance of recreation resonates with an article from 1953, titled 'Language of our time', which Bazin wrote for People et culture, the mother organization of Travail et culture. Emphasizing his interest in popular education as well as his views on film language, he dismisses the disappearance of illiteracy for having been unable to elevate the intellectual and cultural sensibility of the masses and instead praises the emancipatory potential of film: 'during the time of the development of primary schools, new techniques for the diffusion of thought appeared. ${ }^{103}$ Among these modern technologies Bazin counts the telephone:

The car, the telephone, the typewriter are a kind of concrete language spoken by hundreds of thousands of people. Undoubtedly, this universalization of expression of lifestyles needs a corresponding medium of expression, more immediate and with a vocabulary which is itself also concrete and universal: a language of objects. ${ }^{104}$

These technologies, we could call them Bazin's new media, are all means of communication - ways to connect with the world around us. This is indeed what Deligny points out when he laments Bazin's lost tradition in light of semiotics: 'the possibility of linking man to the world by other means than language'. Like the bandage in Van Gogh's portrait, the telephone in Bazin's photograph immediately refers to off-screen reality; for Bazin, it would be senseless to ignore this indispensable link between film and reality. From this perspective, the kind of semiotics for which 'language is everything' is indeed much more precarious: a word - for example 'telephone' - could

102 In 'The Elevator and the Telephone', Michel Chion considers the telephone in relation to film language as follows: 'In fact it turns out that the elevator and the telephone are perhaps at the origin of the language of cinema. Indeed, the telephone, and its predecessor the telegraph, in making possible an immediate interaction from a distance, inspired parallel montage, without which cinema never would have gone very far.' (Chion, 2013, p. 453).

103 Bazin, 1953e, EC p. 1078.

104 Ibid., EC p. 1079. 

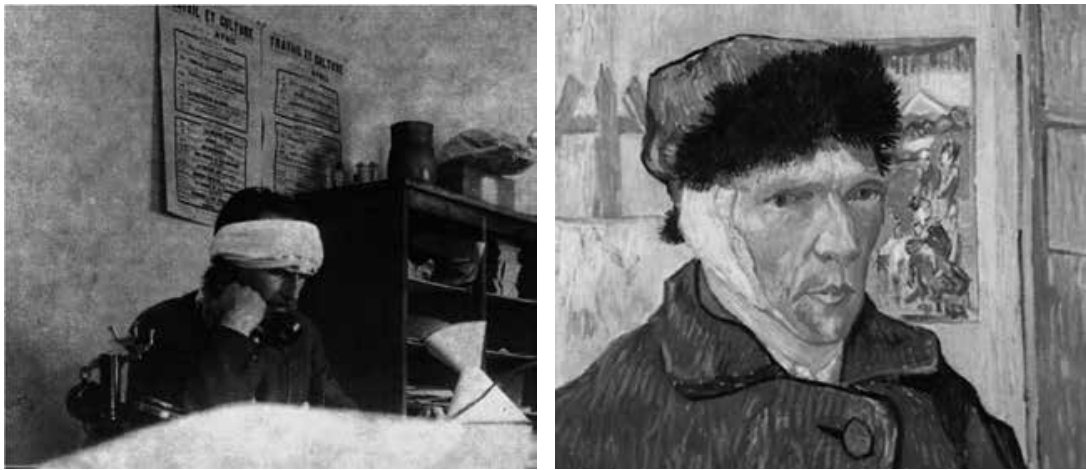

Fig. 27-28 Bazin copies Self-portrait with Bandaged Ear, Vincent van Gogh (1889)

also refer to the salt at the table. ${ }^{105}$ Cinema, on the contrary, signifies by reference to concrete objects in reality: it is the world (signified) in its own image (signifier). In realist semantics, then, the traditional distinction between signifier (any object, or stylistic means) and signified (meaning), which in semiotics constitutes the sign, is abolished: instead, form and content are inseparable.

Historically speaking, Bazin's generation is indeed characterized by the realist approach to film, which in fact almost exclusively carries his signature. Throughout the previous chapters, I have shown that the myth of total cinema represents Bazin's opposition to the prescriptive silent film theories. After Bazin, this realism was in turn heavily criticized by semiotic film studies from the sixties onwards. 'The Humanities', Joubert-Laurencin explains, 'in their academic dimension, when they started being interested in cinema, have moved beyond Bazin back to preceding theories on expressive film language, with its technically coded structure'. ${ }^{106}$ In the following and final chapter of this study, I want to test the validity of this realist momentum, specifically focussing on his myth of total cinema, within a contemporary media landscape. A close examination of Bazin's reformulation of form and content in art criticism will first bring us right to the heart of a fierce discussion among Bazin and his colleagues on film style and meaning, pushing Bazin from his acquired realist position almost into the camp of

105 On this topic, see also my brief analysis of the film Dogtooth (Yorgos Lanthimos, 2010), presented at the Encontro Fernand Deligny, Rio de Janeiro (August 2016) and published in its conference proceedings as 'Can you 'ear me? L'autoportrait de Vincent Van Gogh vu par Bazin et Deligny.' Cadernos Deligny, Vol.1, No.1 (2018): pp. 225-238.

106 Joubert Laurencin, 2001, p. 115 . 
the formalists. Against Bazin, Georges Sadoul for example argued that 'if cinema is a language, it is so primarily because it tells stories. Therefore, the content of the scenarios is essential, because it must dictate the style. ${ }^{107}$ As I hope to demonstrate below, Bazin radically counters this position: to him, form and content (in film and in film criticism) are synthetic. Ultimately, then, this discussion on content and form will lead to an examination of his prescient views at the time on three-dimensional cinema, and enable a concluding discussion on Virtual Reality from a realist perspective.

\section{Bibliography}

Alpers, Svetlana (1983). The Art of Describing. Dutch Art in the Seventeenth Century. Chicago: Chicago University Press.

Andrew, Dudley (2010). What Cinema Is! West-Sussex: Wiley-Blackwell.

--- (2011). 'Malraux, Bazin, and the Gesture of Picasso.' In: Opening Bazin: Postwar Film Theory and Its Aftermath. Eds. Dudley Andrew and Hervé Joubert-Laurencin. New York: Oxford University Press, pp. 153-166.

--- (2013). André Bazin. New York: Oxford University Press.

Artaud, Antonin (1947). 'Van Gogh, the Man Suicided by Society.' Transl. Helen Weaver. In: Antonin Artaud: Selected Writings. Ed. Susan Sontag. Berkeley: University of California Press (1988): pp. 483-512.

Auden, W.H. (1939). 'Musée des Beaux-Arts.' In: Collected Poems: Auden. Ed. Edward Mendelson. New York: Vintage Books (1991): p. 179.

Baldwin, Robert (1986). 'Peasant Imagery and Bruegel's Fall of Icarus.' Kunsthistorisk Tidskrift/ Journal of Art History, Vol. 55, No. 3: pp. 101-104.

Barthes, Roland (1973). S/Z: An Essay. London: Cape, 1974.

Bataille, Georges (1930). 'Sacrificial Mutilation and the Severed Ear of Vincent Van Gogh.' Transl. Allen Stoekl. In: Visions of Excess: Selected Writings, 1927-1939. Ed. Allen Stoekl. Minneapolis: University of Minnesota Press (1985): pp. 61-72.

--- (1937). 'Van Gogh as Prometheus.' Transl. Annette Michelson. October, Vol. 36 (Spring 1986): pp. 58-6o.

Bazin, André (1945). 'Ontologie de l'image photographique.' Qu'est-ce que le cinéma? Paris: Éditions du Cerf (2008): pp. 9-18. EC PO, 1.

--- (1946/1958). 'Le Mythe du cinéma total.' Qu'est-ce que le cinéma? Paris: Éditions du Cerf (2008): pp. 19-24. EC OP I, 2.

--- (1947c). 'Le film scientifique: Beauté du hasard.' Écran français, No. 121 (21 October). EC IV, 339.

--- (1948c). 'Le Réalisme cinématographique et l'école italienne de la Libération.' Esprit, No. 141 (January). EC V, 362.

--- (1948d). 'William Wyler ou le janséniste de la mise en scène.' Qu'est-ce que le cinema? Vol. 1 : Ontologie et langage. Paris: Éditions du Cerf (1958): pp. 149-173. EC V, 382.

--- (1949b). 'A Propos de Van Gogh. L'Espace dans la peinture et le cinéma.' Arts, No. 210 (15 April). EC VII, 581.

107 Sadoul, 1948, p. 71. 
--- (1952d). 'Peinture et cinéma.' Qu'est-ce que le cinéma? Paris: Éditions du Cerf (2008): pp. 187192. EC OP II, 6.

--- (1952f). 'Pour un cinéma impur. Défense de l'adaptation.' Qu'est-ce que le cinéma? Paris: Éditions du Cerf (2008): pp. 81-106. EC X, 923.

--- (1953e). 'Le langage de notre temps.' In: Regards neufs sur le cinéma. Eds. Jacques Chevallier and Max Egly. Paris: Éditions du Seuil (1963): pp. 5-17. EC XII, 1202.

--- (1956a). 'Grâce à la T.V. on peut maintenant "Descendre en soi-même”.' Radio cinéma télévision, No. 312 (8 January). EC XVIII, 1952.

--- (1956c). 'Le Monde du silence.' France observateur, No. 303 (1 March). EC XIX, 1997.

--- (1956f). 'Un film bergsonien: Le Mystère Picasso.' Qu'est-ce que le cinéma? Paris: Éditions du Cerf (2008): pp. 193-202. EC XIX, 2059.

--- (1957a). 'La Vie passionnée de Vincent Van Gogh.' Éducation nationale, No. 6 (7 February). EC XX, 2229.

Bernstock, Judith E. (1993). 'Classical Mythology in Twentieth-Century Art: An Overview of a Humanistic Approach.' Artibus et Historiae, Vol. 14, No. 27: pp. 153-183.

Blume, Anna (1995). 'In the Wake of Production: A Study of Bruegel's Landscape with the Fall of Icarus.' In: The Delegated Intellect: Emersonian Essays on Literature, Science, and Art in Honor of Don Gifford. Ed. Donald E. Morse. New York: Peter Lang, pp. 237-264.

Boime, Albert (1984). 'Van Gogh's Starry Night: A History of Matter and a Matter of History.' Arts Magazine, Vol. 59, No. 4 (December): pp. 86-103.

Breton, André and Marcel Duchamp (1942). First Papers in Surrealism. New York: Coordinating Council of French Relief Societies.

Chion, Michel (2013). 'The Elevator and the Telephone.' A Companion to François Truffaut. Eds. Dudley Andrew and Anne Gillian. West-Sussex: Wiley-Blackwell, pp. 448-453.

Conley, Tom (2007). Cartographic Cinema. Minneapolis: University of Minnesota Press.

Dalle Vacche, Angela (2014). 'The Art Documentary in the Postwar Period.' Aniki: Portuguese Journal of the Moving Image, Vol. 1, No. 1: pp. 292-313.

--- (2011). 'The Difference of Cinema in the System of the Arts.' In: Opening Bazin: Postwar Film Theory and Its Aftermath. Eds. Dudley Andrew and Hervé Joubert-Laurencin. New York: Oxford University Press, pp. 142-152.

Daney, Serge (1991). 'The Demise of Critical Thinking.' Transl. Stoffel Debuysere. Diagonal Thoughts. [Accessed 30/10/2017] <http://www.diagonalthoughts.com/?p=1521>.

De Tolnay, Charles (1935). Pierre Bruegel l'ancien. Brussels: Nouvelle société d'éditions.

De Vries, Lyckle (2003). 'Bruegel's Fall of Icarus: Ovid or Solomon?' Simiolus: Netherlands Quarterly for the History of Art, Vol. 30, No; 1-2: pp. 4-18.

Deligny, Fernand (1955). 'La caméra, outil pédagogique.' Vers l'éducation nouvelle: pp. 414-417.

---(1989). 'A propos d'un film a faire.' In: CEuvres. Ed. Sandra Alvarez de Toledo. Paris: L'Arachnéen (2007): pp. 1751-1752.

--- (1990). 'Ce qui ne se voit pas.' In: CEuvres. Ed. Sandra Alvarez de Toledo. Paris: L'Arachnéen (2007): pp. 1774-1775.

Duhem, Pierre (1905). Sōzein ta phainomena: essai sur la notion de théorie physique de Platon à Galilée. Paris: Librairie scientifique A. Hermann et fils.

Gerardin, Timothée. 'À la surface.' Le Rotor*, No. 10 [Accessed: 20/02/2015] <http://lerotor.free. fr/article.php3?id_article $=91>$.

Glück, Gustav (1936). Pieter Bruegel the Elder. Transl. E.B. Shaw. London: Commodore.

Harries, Karsten (2002). Infinity and Perspective. Cambridge: The MIT Press.

Heidegger, Martin (1935-6). 'The Origins of the Work of Art.' In: Off the Beaten Track. Transl. Julian Young and Kenneth Haynes. Cambridge: Cambridge University Press (2002): pp. 1-56. 
Huygens, Christiaan (1659). 'On Centrifugal Force.' Transl. M.S. Mahoney. [Accessed 20/02/2015] <https://www.princeton.edu/ hos/mike/texts/huygens/centriforce/huyforce.htm>.

Joret, Blandine (2018). 'Can you 'ear me? L'autoportrait de Vincent Van Gogh vu par Bazin et Deligny.' Cadernos Deligny, Vol.1, No.1: pp. 225-238.

Joubert-Laurencin, Hervé (2001). 'SA.B./S.D. ou les frères passeurs.' Serge Daney: après, avec. Trafic, No. 37 (Spring): pp. 107-116.

--- (2014). Le Sommeil paradoxal: écrits sur André Bazin. Montreuil: Les Éditions de l'CEil

Kal, Jan (1974). 'De val van Icarus,' n. pag. [Accessed 26/04/2019] <https://beeldgedicht.info/ poezie/algemeen/kal-breughel>.

Leirens, Jean (1954). Le Cinéma et le temps. Paris: Éditions du Cerf.

Lubin, Albert J. (1972). Stranger on the Earth: A Psychological Biography of Vincent van Gogh. New York: Henry Holt and Company.

Marcel, Gabriel (1948). 'Les Conditions d'une rénovation de l'art.' In: Débats sur l'art contemporain. Tome 3. Neuchâtel: Les Éditions de la Baconnière, pp. 169-204.

Naifeh, Steven and Gregory White Smith (2011). Van Gogh: The Life. New York: Random House.

Nemerov, Alexander (2005). 'The Flight of Form: Auden, Bruegel, and the Turn to Abstraction in the 1940s.' Critical Inquiry, Vol. 31, No. 4: pp. 780-810.

Newton, Isaac (1684). The Principia: Mathematical Principles of Natural Philosophy. Transl. Bernard Cohen, Anne Whitman and Julia Budenz. Berkeley: University of California Press (1999).

Sadoul, Georges (1948). 'La Métaphysique de la profondeur de champ.' 1895: Revue d'histoire du cinéma, No. 67 (Summer 2012): pp. 132-137.

Sartre, Jean-Paul (1946). 'Existentialism Is a Humanism.' Transl. Philip Mairet. In: Existentialism from Dostoyevsky to Sartre. Ed. Walter Kaufman. New York: Penguin Group (1975): pp. 345-368.

Schapiro, Meyer (1968). 'A Note on Heidegger and Van Gogh.' In: Theory and Philosophy of Art: Style, Artist and Society. New York: George Braziller (1998): pp. 135-142.

Stendhal (1862). Rome, Naples et Florence. Paris: Gallimard (1987).

Virilio, Paul (1989). War and Cinema: Logistics of Perception. Transl. Patrick Camiller. London: Verso. Whitney, Charles A. (1988). 'The Skies of Van Gogh.' Art History, Vol. 9, No. 3: pp. 351-362.

\section{Other sources}

Bazin, André, Georges Emmanuel Clancier, Gabriel Marcel and Adolphe Portmann (1948). 'L'Art contemporain: faut-il renouveler l'art?' Tribune de Paris (2o September) [Accessed: 20/02/2015] <http://boutique.ina.fr/art-et-culture/arts-du-spectacle/audio/PHD85011662/lart-contemporain-faut-il-renouveler-l-art.fr.html>.

\section{Used translations}

Bataille, Georges (1937). 'Van Gogh as Prometheus.' Transl. Annette Michelson. October, Vol. 36 (Spring 1986): pp. 58-6o.

Bazin, André. 'Science Film: Accidental Beauty.' Transl. Jeanine Herman. In: Science Is Fiction: The Films ofJean Painlevé. Eds. Andy Masaki Bellour, Marina McDougall and Birgitte Berg, Cambridge: The MIT Press (2000): pp. 114-147. 
---. What Is Cinema? Vol. 1 \& 2. Transl. Hugh Gray. Berkeley: University of California Press (2005).

---. What Is Cinema? Transl. Timothy Barnard. Montreal: Caboose (2009).

---.André Bazin's New Media. Transl. Dudley Andrew. Berkeley: University of California Press (2014).

\section{Filmography}

The Blood of a Poet [Le Sang d'un poète] (Jean Cocteau, 1930)

Rubens (Paul Haesaerts \& Henri Storck, 1948)

Van Gogh (Alain Resnais, 1948)

Journal d'un curé de campagne (Robert Bresson, 1954)

Lust for Life (Vincente Minelli, 1956)

The Mystery of Picasso [Le Mystère Picasso] (Henri-Georges Clouzot, 1956)

The Silent World [Le Monde du silence] (Jacques-Yves Cousteau \& Louis Malle, 1956)

Blue Velvet (David Lynch, 1986)

Tableau avec chute (Claudio Pazienza, 1996)

The Stendhal Syndrome (Dario Argento, 1996)

The Gladiator (Ridley Scott, 2002)

Dogtooth (Yorgos Lanthimos, 2010)

\section{Illustrations}

Figure 9. $\quad$ Pieter Bruegel the Elder, Landscape with the Fall of Icarus (ca. 1558), oil on canvas, the Royal Museums of Fine Arts of Belgium

Figure 10. Etching by Pieter Bruegel the Elder, A Man-of-War near the Coast, with the Fall of Icarus (ca. 1562), courtesy of Fine Arts Museums of San Francisco, California USA

Figure $11 \quad$ Cut-out by André Breton, included in First Papers of Surrealism (1941)

Figure 12-13. Film stills from The Mystery of Picasso (Henri-Georges Clouzot, 1956)

Figure 14-19. Film stills with Rembrandt's Nightwatch from The Stendhal Syndrome (Dario Argento, 1996)

Figure 20-22. Film stills from Van Gogh (Alain Resnais, 1948)

Figure 23-24. Film stills from Lust for Life (Vincente Minelli, 1956)

Figure 25-26. Film stills from Blue Velvet (David Lynch, 1986)

Figure 27. André Bazin in his office at Travail et culture, 1948, taken either by Janine Bazin or Chris Marker

Figure 28. Vincent van Gogh's Self-portrait with Bandaged Ear (1889), oil on canvas, The Courtauld Institute of Art 
